\title{
Metabolic Control by DNA Tumor Virus-Encoded Proteins
}

\author{
Martin A. Prusinkiewicz ${ }^{1}$ (D) and Joe S. Mymryk ${ }^{1,2,3,4, *(\mathbb{D})}$ \\ 1 Department of Microbiology and Immunology, Western University, London, ON N6A 3K7, Canada; \\ mprusink@uwo.ca \\ 2 Department of Otolaryngology, Head \& Neck Surgery, Western University, London, ON N6A 3K7, Canada \\ 3 Department of Oncology, Western University, London, ON N6A 3K7, Canada \\ 4 London Regional Cancer Program, Lawson Health Research Institute, London, ON N6C 2R5, Canada \\ * Correspondence: jmymryk@uwo.ca; Tel.: +1-519-685-8600 (ext. 53012)
}

\section{check for}

updates

Citation: Prusinkiewicz, M.A. Mymryk, J.S. Metabolic Control by DNA Tumor Virus-Encoded Proteins. Pathogens 2021, 10, 560. https:// doi.org/10.3390/pathogens10050560

Academic Editor: Anna Honko

Received: 15 April 2021

Accepted: 4 May 2021

Published: 6 May 2021

Publisher's Note: MDPI stays neutral with regard to jurisdictional claims in published maps and institutional affiliations.

Copyright: (c) 2021 by the authors. Licensee MDPI, Basel, Switzerland. This article is an open access article distributed under the terms and conditions of the Creative Commons Attribution (CC BY) license (https:/ / creativecommons.org/licenses/by/ $4.0 /)$.

\begin{abstract}
Viruses co-opt a multitude of host cell metabolic processes in order to meet the energy and substrate requirements for successful viral replication. However, due to their limited coding capacity, viruses must enact most, if not all, of these metabolic changes by influencing the function of available host cell regulatory proteins. Typically, certain viral proteins, some of which can function as viral oncoproteins, interact with these cellular regulatory proteins directly in order to effect changes in downstream metabolic pathways. This review highlights recent research into how four different DNA tumor viruses, namely human adenovirus, human papillomavirus, Epstein-Barr virus and Kaposi's associated-sarcoma herpesvirus, can influence host cell metabolism through their interactions with either MYC, p53 or the pRb/E2F complex. Interestingly, some of these host cell regulators can be activated or inhibited by the same virus, depending on which viral oncoprotein is interacting with the regulatory protein. This review highlights how MYC, p53 and pRb/E2F regulate host cell metabolism, followed by an outline of how each of these DNA tumor viruses control their activities. Understanding how DNA tumor viruses regulate metabolism through viral oncoproteins could assist in the discovery or repurposing of metabolic inhibitors for antiviral therapy or treatment of virus-dependent cancers.
\end{abstract}

Keywords: glycolysis; cellular respiration; mitochondria; oncovirus; metabolism; MYC; pRb; p53; oncoprotein; cancer

\section{Introduction}

Virally encoded oncogenes execute essential functions that allow DNA tumor viruses to reprogram cellular metabolism. Despite the variety of sizes and functionalities between the different oncoproteins encoded by different DNA tumor viruses, there are a few common targets that could be attractive candidates for future work that explores methods of targeting virally induced metabolic reprogramming for therapy. These include MYC, p53 and $\mathrm{pRb} / \mathrm{E} 2 \mathrm{~F}$, each of which has a unique set of metabolic targets. This review will outline how the host cell metabolic regulators MYC, p53 and pRb/E2F can, in turn, be targeted by DNA tumor virus proteins expressed by human adenovirus (HAdV), human papillomavirus (HPV), Epstein-Barr virus (EBV) and Kaposi's sarcoma-associated herpesvirus (KSHV) during infection or in virus-dependent cancers.

\subsection{MYC Metabolic Targets}

MYC is a transcriptional regulator known to activate the transcription of genes involved in glycolysis, glutaminolysis, nucleotide synthesis and fatty acid synthesis [1-4]. As MYC is a transcription factor, this typically occurs through MYC-induced transcriptional upregulation of metabolic genes. This includes $L D H A$, which encodes an enzyme that converts pyruvate to lactate [2]. Another MYC-upregulated metabolic gene is GLUT1, which encodes a major glucose transporter [5]. The glutamine transporter encoded by SLC1A5 is 
also upregulated by MYC [6]. As a result of increased MYC-induced glycolysis, the pentose phosphate pathway (PPP) is upregulated [7], and MYC is directly responsible for inducing transcription of the PPP enzyme-encoding gene PRPS2 [8]. Many other nucleotide synthesis genes are upregulated by MYC [4]. In addition, a multitude of genes involved in fatty acid synthesis are upregulated by MYC, including ACLY, ACACA, FASN and SCD [1,9]. Finally, the processes of mitochondrial fusion and fission are reported to be under some level of control by MYC, which ultimately controls oxidative phosphorylation [10].

MYC itself can be regulated by a variety of pathways that can be aberrantly regulated in disease [11]. The PI3K/AKT signaling pathway increases MYC activity by inhibiting negative regulators of MYC [12]. The MAPK/ERK pathway also inhibits a negative regulator of MYC activity, MAD1 [13]. In terms of transcriptional regulation, TGF- $\beta$ signaling through SMAD2/3 represses MYC gene transcription [14]. JAK/STAT signaling can regulate $M Y C$ transcription via a super enhancer region of the gene [15]. Likewise, estrogen receptors can bind $M Y C$ enhancers to regulate their transcription [16]. The Wnt signaling pathway can similarly regulate $M Y C$ transcription through Wnt response elements [17]. Finally, the Notch signaling pathway interacts with a complex that binds MYC enhancers [18].

Given that MYC impinges on so many metabolic pathways, understanding which DNA tumor viruses are capable of altering MYC activity could be important for understanding the mechanisms behind DNA tumor virus metabolic reprogramming.

\section{2. $p 53$ Metabolic Targets}

Another protein commonly affected by viral oncoproteins is the tumor suppressor p53 encoded by the TP53 gene. p53 is activated by cellular stress, including DNA damage, hypoxic conditions or oncoprotein activity [19-22]. These stresses trigger p53-mediated DNA damage repair, apoptosis, cell cycle arrest and metabolic pathways to counteract or mitigate the damage they cause [23-27]. p53 itself is regulated by the E3 ubiquitin ligase MDM2 to ensure that levels of the protein remain low under permissive, unstressed conditions [28]. In contrast, the phosphorylation of p53 at critical serine and threonine amino acid residues serves to stabilize the protein [29]. Due to its major role in counteracting cellular stress, p53 is one of the most frequently mutated genes in cancer [30].

Many viral oncoproteins inhibit the activity of p53, which, in turn, can increase the glycolytic activity of the infected cell [26]. This is because activated wild-type p53 can increase the activity of $\mathrm{SCO} 2$, which is involved in the assembly and regulation of the COX proteins that make up the mitochondrial cellular respiration complex IV [26]. Therefore, by inhibiting p53, viral oncoproteins inhibit mitochondrial function, which can subsequently trigger the upregulation of glycolytic pathways. p53 expression can also decrease the levels of the glucose transporters Glut1 and Glut4 [31], as well as the glucose metabolism enzyme PGM [32]. p53 increases expression of the glycolytic inhibitor TIGAR [33]. Understanding whether the inhibition of p53 by DNA tumor virus oncoproteins has any substantial effect on the resulting metabolic phenotype of the infected cell could further emphasize the importance of p53 in viral infection and virus-positive cancers.

\section{3. $p R b / E 2 F$ Metabolic Targets}

DNA tumor viruses commonly target the activity of $\mathrm{pRb}$, which is responsible for inhibiting the E2F family of transcription factors [34]. Like p53, pRb is typically regulated by E3 ubiquitin ligases, including MDM2, which cause the degradation of $\mathrm{pRb}$ [35]. MDM2 activity is triggered by the phosphorylation of $\mathrm{pRb}$, regulated by proteins such as CDK4, CDKN2A and CCND1 [36,37]. Acetylation of pRb, induced by p300, inhibits the phosphorylation of $\mathrm{pRb}$ [38]. $\mathrm{pRb}$ can be SUMOylated, which leads to the expression of genes involved in cellular senescence [39]. Deubiquitinases, such as HAUSP, prevent $\mathrm{pRb}$ degradation [40].

In addition to regulating cell growth and proliferation through the cell cycle, E2F regulates the expression of a multitude of metabolic enzymes that are involved in glycolysis, 
the tricarboxylic acid (TCA) cycle, cellular respiration and nucleotide synthesis, helping to provide the energy and substrates necessary for the cell division cycle [41]. For example, E2F is responsible for regulating the expression of the glycolytic enzyme PFKFB [42,43]. E2F can also increase the expression of PDK4, which inhibits the entry of pyruvate into the TCA cycle, further promoting glycolysis [44]. Another way in which E2F expression leads to a metabolic phenotype that is more akin to cancer cells is by activating glutaminolysis, the process of metabolizing glutamine into TCA cycle metabolites $[45,46]$. E2F1 also plays a prominent role in inducing the expression of nucleotide synthesis genes [47]. As certain oncoproteins are capable of binding pRb, thus activating E2F, the ability of E2F to influence cellular metabolism is an important area of cancer research.

\section{Regulation of MYC by DNA Tumor Virus Oncoproteins}

\subsection{Regulation of MYC by HAdV}

The most widely recognized oncoproteins in HAdV that can regulate MYC are E1A [48] and E1B [49] (Figure 1). E4orf1 [50] and E4orf6 [51] are two other HAdV proteins that have a role in MYC regulation (Figure 1). Recent advances in proteomics have identified that HAdV consistently upregulates MYC throughout infection [52].

In a series of elegant experiments, E4orf1 was identified to be a significant HAdV protein responsible for upregulating MYC expression during infection and contributing to the associated increases in glycolysis and glutaminolysis observed in HAdV-infected cells [53,54]. E4orf1 can upregulate MYC expression through a variety of signaling pathways that impinge on MYC activity, namely those including either EGFR, INSR/IGF1R or PI3K [55].

The HAdV oncoprotein E1A is reported to influence MYC activity through the TRRAP protein [56]. E1A can also stabilize MYC itself [57]. Additionally, a complex between E1A and p400 was found to target MYC and bring both p400 and MYC to the promoter regions of genes and increase their transcription [58]. E1A has also been reported to disrupt p300-mediated repression of MYC [59]. All of these interactions between E1A and MYC could account for our recent findings, which illustrate that glycolysis can be upregulated by E1A [60]. While there are examples of select regions of E1A being able to inhibit MYC through p300/CBP or TRRAP [61], this could suggest that, rather than completely abolishing MYC activity, E1A may selectively modulate which MYC targets are transcribed depending upon which regions of E1A are available for interaction with MYC and through which complexes the E1A/MYC interaction occurs.

The HAdV protein E4orf6 can influence the upregulation of MYC in two ways. One is via stabilization of the $M Y C$ transcript, presumably leading to greater production of MYC [62]. A second mechanism by which E4orf6 can influence MYC activity is through further stabilization of the interaction between E1A and MYC [53]. Additionally, both E4orf6 and E1B-55K have been reported to downregulate MYC expression [57], a contradictory function for E4orf6. Speculatively, different outcomes of E4orf6 effects on MYC could occur at different stages of infection. This could depend on the HAdV type under investigation or may be dependent on which other viral or host cell proteins are available for interacting with E4orf6 in the context of different experimental systems.

In contrast to most of the HAdV products described above, E4orf4 inhibits MYC during infection [63]. It should be noted that E4orf4 is not defined as a HAdV oncoprotein, and this study used HEK293 cells, which already express E1A and E1B [64], thus potentially influencing the results. In a contradiction to the report above, E4orf4 has also been found to cause an increase in MYC protein levels [65]. However, this study examined the E4orf4 protein in isolation as a vector without the full complement of HAdV proteins that would be expressed during infection, which could explain this contrasting observation.

Taken together, the control of MYC expression, localization and activity is clearly an important task during HAdV infection, given that so many viral proteins target this cellular hub to reprogram gene expression in the host cell. It is clear that at least some of these impact cellular metabolism $[60,66]$, but much remains to be learned. 


\subsection{Regulation of MYC by HPV}

Numerous reports have identified functional effects of the HPV E6 and E7 oncoproteins on MYC (Figure 1). Both E6 and, albeit less efficiently, E7 have been reported to upregulate MYC $[67,68]$. With respect to E6, the association with MYC has been investigated primarily in the context of upregulation of hTERT expression. Several studies found that MYC physically associated with E6 and was critical for E6 activation of hTERT transcription $[68,69]$. However, it has become relatively clear that E6 does not induce hTERT transcription simply by inducing expression of MYC, but rather the involvement of other host cell proteins is required [70]. Somewhat confusingly, it was reported that E6 can also stimulate the degradation of MYC [71]. These differences may be attributed to cell type, as this contradictory result was observed in a neuroblastoma cell line [71]. This does not represent the tissue type typically infected by HPV, which is better represented by human foreskin keratinocytes [68]. Perhaps the most convincing evidence that E6 stimulates MYC activity, and that this overexpression is crucial to E6-mediated transformation by HPV, is the ability of MYC overexpression to immortalize cells in cooperation with E7. Thus, E7 and MYC cooperate in a similar manner, but not identical to E6 and E7, to induce immortalization [72].

As for the E7 oncoprotein, it is possible that HPV18 E7 can interact with MYC to promote MYC-regulated transcription [73,74]. It is also possible that E7 can promote MYC activity indirectly, as a study utilizing HPV16 E7 found that E7 could inhibit MIZ1, a negative regulator of MYC function [75]. The result of this was increased MYC function. Perhaps somewhat contradictorily, two studies of HPV+ head and neck squamous cell carcinoma tissue samples did not identify an association between the cancer and increased MYC expression [76,77]. However, another study of patient tissues found that HPV integration within the tonsillar crypt was associated with MYC amplification and overexpression [78]. The upregulation of MYC by HPV, predominantly enacted through the E6 oncoprotein [68], could serve to increase the expression of metabolic genes involved in glycolysis, glutaminolysis and nucleotide synthesis [79], but this remains to be conclusively determined.

\subsection{Regulation of $M Y C$ by $E B V$}

In B cell lymphomas, EBV drives MYC expression in a variety of ways (Figure 1). Perhaps the most common EBV-induced change to MYC expression is in the form of a common MYC gene translocation event in EBV-positive Burkitt's lymphoma [80]. In this translocation event, $M Y C$ is translocated to the immunoglobulin heavy locus gene, IGH, where it comes under the control of the highly active IGH regulatory region [81]. This leads to constitutive expression of MYC in Burkitt's lymphoma [81,82]. However, the expression of multiple EBV viral proteins has also been associated with MYC expression in B cell cancers. EBNA2 was noted to activate $M Y C$ transcription in primary B lymphocytes [83]. EBNA2 can also upregulate MYC protein levels [84]. There is evidence that EBNA2 can increase interactions between enhancers and promoters upstream of $M Y C$ through the chromatin regulator SMARCA4 [85]. EBNA2 can bind DNA regions termed EBV-super enhancers, in which a complex of EBV latent proteins, including EBNA3A and EBNA3C, as discussed below, can increase the expression of host cell genes, such as MYC [86]. EBNA2 may also increase the expression of non-coding enhancer RNAs (eRNAs) that regulate MYC transcription [87]. EBNA2-driven MYC expression can upregulate mitochondrial one-carbon metabolism, specifically the de novo synthesis of serine, which contributes to nucleotide synthesis, mitochondrial NADPH production and production of the antioxidant glutathione [88]. Other metabolic pathways upregulated by EBNA2-driven expression of MYC in B cells include cholesterol and lipid biosynthesis [89,90].

Two other EBNA proteins, EBNA3A and EBNA3C, also contribute to MYC expression. Both EBNA3A and EBNA3C contribute to the EBV super enhancer structure that ensures the presence of transcription factors at the MYC transcription start site via enhancerpromoter looping [91]. Additionally, EBNA3C stabilizes the interaction between MYC and 
MYC target promoters, essentially increasing MYC activity [92]. To further augment MYC expression, EBNA3A and EBNA3C cooperate to epigenetically repress BCL2L11 expression, which encodes a negative regulator of MYC. BCL2L11 expression can be induced by MYC in the absence of EBNA3A and EBNA3C in a negative feedback mechanism [93-95].

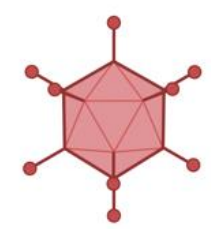

HAdV

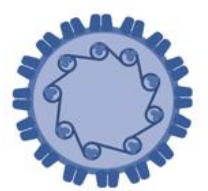

HPV

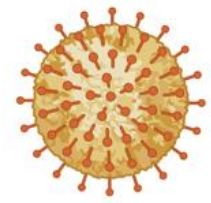

EBV

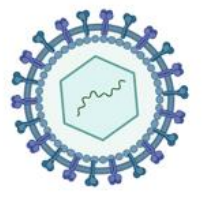

KSHV

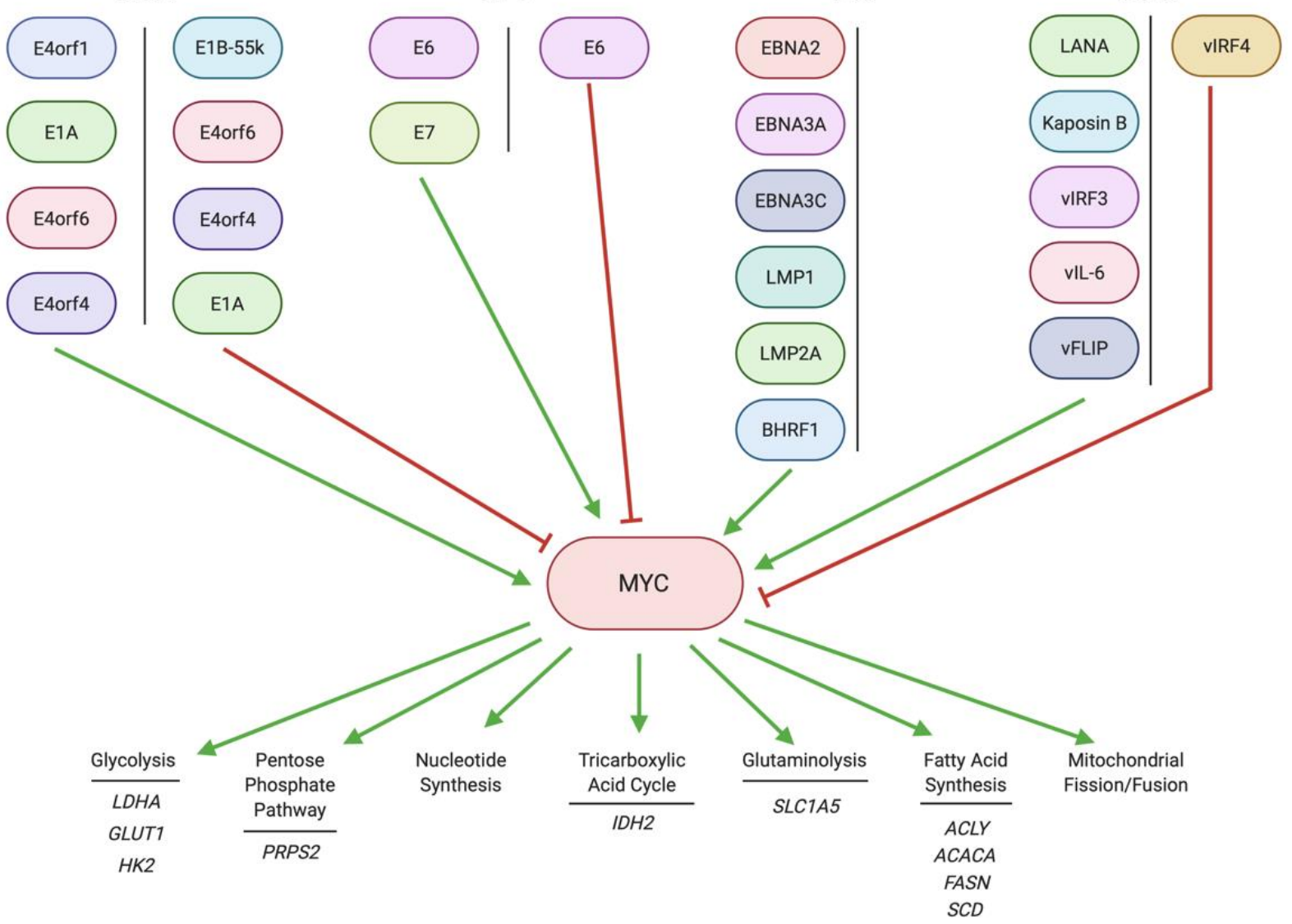

Figure 1. Regulation of MYC by DNA tumor virus oncoproteins. A number of HAdV proteins are reported to both positively and negatively regulate MYC, depending on the cellular and infection context. The HPV oncoprotein E6 is also reported to both activate and inhibit MYC activity, while E7 is a positive regulator of MYC. Multiple EBV viral proteins upregulate MYC activity. KSHV viral proteins generally activate MYC, although one KSHV protein, vIRF4, can downregulate MYC. MYC is a key regulator, primarily as a transcription factor, for many metabolic genes and pathways. Created with BioRender.com.

The EBV latent membrane proteins also play a role in increasing MYC expression in EBV-driven cancers. In B cells, LMP1 can increase MYC transcription and resulting MYC protein expression via the JAK/STAT pathway [96]. STAT3 in particular is upregulated in EBV-positive nasopharyngeal carcinoma cell lines [97,98]. Additionally, in EBV-induced nasopharyngeal carcinoma, LMP1 facilitates increased interactions between MYC and the MYC target genes HK2 and IDH2, which encode enzymes in glycolysis and the TCA cycle, respectively [99-101]. This MYC stabilization occurs through an LMP1 signaling pathway that involves PI3K/AKT/GSK3 $\beta$ and FBXW7 signaling [100,101]. The importance of the LMP1-mediated MYC activation pathway was emphasized by a study in which the histone deacetylase inhibitor romidepsin was found to be cytotoxic to an EBV-positive diffuse 
large B-cell lymphoma in both a cell culture and a mouse xenograft model by reducing the expression of both LMP1 and MYC [102].

In addition to causing increased MYC expression and activity, LMP1 downregulates the $\alpha$-isoform of the MYC repressor PRDM1, which further accentuates LMP1-driven MYC activation [103]. In a similar manner, LMP2A can facilitate MYC activity by enhancing the degradation of the MYC inhibitor and tumor suppressor, CDKN1B [104]. LMP2A can also increase the translation of MYC, but not the transcription of $M Y C$, through the PI3K/AKT/mTOR signaling pathway [105]. Finally, the EBV pro-survival BCL-2 homologue, BHRF1, enhanced MYC activity in a mouse model of Burkitt's lymphoma [106]. EBV appears to tightly regulate MYC in infected B cells to modulate lytic reactivation that would otherwise occur in the absence of MYC [107].

Interestingly, the regulation of MYC by EBV oncoproteins appears to be relatively minimal in EBV-associated gastric cancer (EBVaGC). At most, MYC may be upregulated in EBVaGC during its early stages [108]. However, at later times during the progression of EBVaGC, MYC is either downregulated $[108,109]$ or MYC expression does not correlate with EBV expression at all [110-112]. These findings suggest that MYC may not have a role in EBV-induced metabolic alterations associated with EBVaGC. However, in most cases, especially in B cell-related cancers, MYC upregulation by EBV drives serine catabolism for nucleotide synthesis, glycine metabolism for glutathione involved in redox metabolism, and lipid synthesis [113].

\subsection{Regulation of MYC by KSHV}

KSHV is capable of regulating MYC function through a number of its latent proteins [114] (Figure 1). The KSHV protein LANA upregulates MYC function through inactivation of GSK-3 [115-117]. The inactivation of GSK-3 is achieved in two ways. Firstly, GSK-3 is removed from the cytoplasmic $\beta$-catenin destruction complex [118], which allows $\beta$-catenin to activate transcription of MYC [117]. Secondly, inactivation of GSK-3 by LANA leads to decreased GSK-3-mediated phosphorylation of Thr58 on MYC, thus stabilizing MYC by preventing its degradation through ubiquitination [116,119]. Additionally, ERK1 is stabilized by LANA, which stimulates the phosphorylation of MYC at Ser62, increasing the transcriptional activity of MYC on its gene targets [116].

MYC can form a complex with kaposin B, which is another KSHV latent protein, to modulate the expression of a wide variety of host microRNAs [120], some of which, such as miR-210 [121-125], miR-3188 [126], miR-483-3p [127], miR-3197 [128], miR-4235p [129], let-7f-5p [130], miR-372-3p [131], miR-9-5p [132,133], miR-489-3p [134], miR-12715p [135], miR-7-5p [136] miR-942-3p [137] and miR-153-3p [138,139], have been linked to metabolism in other diseases. In addition, the KSHV latent protein vIRF3 can stimulate the transcriptional activity of MYC by interacting with Skp2, a transcriptional cofactor that stabilizes and upregulates MYC activity [140]. Another way in which vIRF3 stimulates MYC activity is by inhibiting a negative regulator of MYC, PFDN5 [141]. Finally, vIRF3 may interact with the promoter region of MYC targets, as was demonstrated for CDK4, to increase histone $\mathrm{H} 3$ acetylation, thereby encouraging MYC-mediated transcription of the target [141].

The KSHV latent protein vIRF4 has an inhibitory effect on MYC [142], which assists the latently infected cell to enter the lytic phase of KSHV replication [143]. This MYC-regulated switch between the latent and lytic phases of infection is a parallel between KSHV and EBV infections [143]. vIRF4 appears to suppress MYC activity by limiting the amount of eRNAs produced by cellular IRF4, thereby limiting the super enhancer function of IRF4 and lowering MYC expression [144]. The control of eRNA expression to modulate MYC transcription is another parallel between KSHV and EBV.

The KSHV protein vIL-6, while not directly responsible for upregulating MYC transcription or MYC protein expression, could enhance the oncogenic activities of MYC in a KSHV-associated cancer mouse model [145]. Similarly, the latent protein vFLIP appeared to accelerate lymphoma development in conjunction with MYC in a mouse model [146]. 
KSHV can also influence glutaminolysis through MYC as MYC/MAX and MLXIP/MLX heterodimers that induce expression of the glutamine transporter SLC1A5 [147]. One of the main results of KSHV-mediated upregulation of MYC function is the upregulation of glutamine metabolism, upon which KSHV is particularly reliant [147].

\section{Regulation of p53 by DNA Tumor Virus Oncoproteins}

\subsection{Regulation of $p 53$ by HAdV}

The E1B oncoproteins are the HAdV proteins most directly responsible for binding to and inhibiting the transcriptional activation activity of p53 [148-150] (Figure 2). The E1B-55K isoform of E1B can bind p53 in a complex that involves E4orf6 [151,152]. It appears that this complex can sequester p53 away from the nucleus [153,154]. In addition, E1B-55K can SUMOylate p53 to influence its function [155]. p53 SUMOylation by E1B-55K leads to tethering and colocalization of p53 to E1B-55K, thus decreasing the nuclear mobility of p53 and maximally inhibiting its function [156].

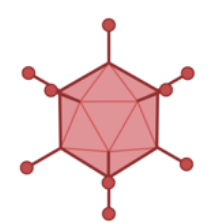

HAdV

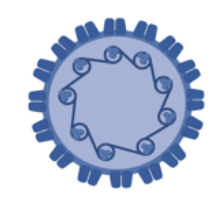

HPV

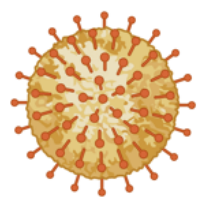

EBV

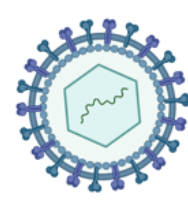

KSHV

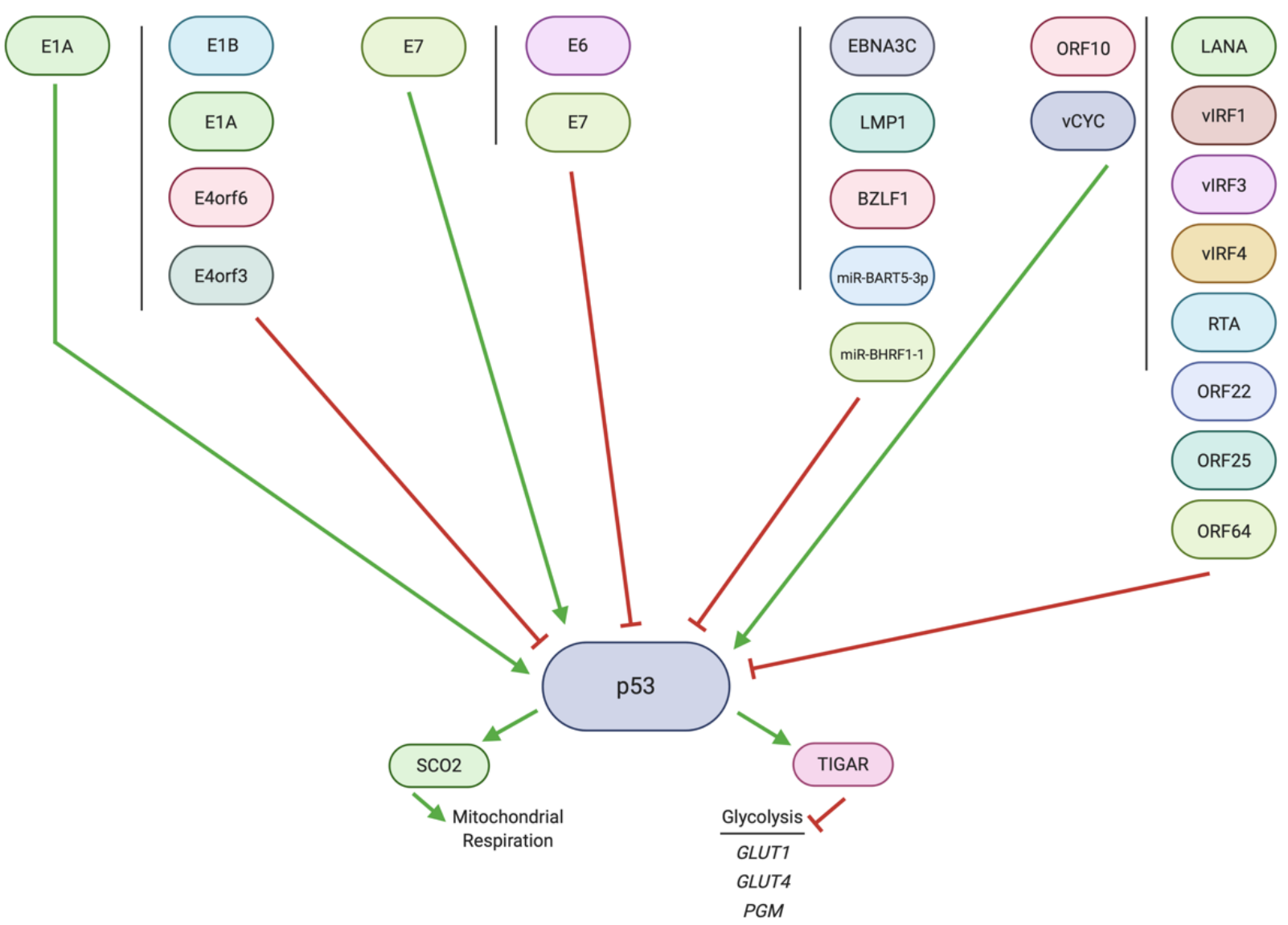

Figure 2. Regulation of p53 by DNA tumor virus oncoproteins. Most HAdV proteins inhibit p53. E1A generally induces p53 activity, but it can also inhibit p53. Like E1A, the HPV protein E7 induces p53 activity, but it has also been reported to inhibit p53. E6 is a p53 inhibitor. Three EBV proteins and two EBV miRNAs can inhibit p53. While most KSHV proteins limit p53 activity, two KSHV proteins, ORF10 and vCYC, can upregulate p53 function. p53 is a pro-apoptotic protein and tumor suppressor that can inhibit glycolysis and encourage mitochondrial respiration. Created with BioRender.com. 
E1B-19K can directly bind p53 within the mitochondria and inhibit mitochondrially mediated p53 induction of apoptosis [157]. E1B-19K can also bind BAK within the mitochondria to competitively inhibit binding by p53, thus blocking apoptosis [157].

The ability of E1A to interact with and affect p53 is more nuanced. It appears that E1A induces apoptosis through p53 and even triggers p53 accumulation [158-160]. The accumulation of p53 triggered by E1A appears to play a role in late viral protein production [161]. For example, p53 contributes to activation of the adenovirus L4 promoter within the major late transcription unit [162]. However, the beneficial contributions of p53 to HAdV replication are somewhat controversial [163].

E1A has also been reported to inhibit the transcriptional activation of target genes by p53 and repress its activity [164,165]. It is possible that this repression occurs through the formation of a complex between E1A, FUBP1 and p53, which serves to sequester p53 away from gene promoter regions [166]. Additionally, E1A and either mutant p53 or an absence of p53 entirely have been reported to transform cells $[167,168]$, which would presumably lead to the induction of cancer-related metabolic pathways.

It is possible that these contradictory results regarding whether E1A stabilizes and activates p53 or represses its activity could be attributed to a variety of factors. For example, E1A may induce p53 in HAdV5-transformed cells or when the E1A protein is expressed alone as a vector within a cell [159]. The induction of p53 may be dependent on the E1A isoform, with the $12 \mathrm{~S}$ isoform inducing apoptosis via p53, while the $13 \mathrm{~S}$ isoform does not [158]. Finally, it could be that E1A inhibits p53 activity in HAdV infection of human cells, where the full extent of viral gene expression and processes can occur [166].

Two of the HAdV E4 proteins have been reported to contribute to p53 inhibition. E4orf6 inhibits the transcriptional activity of p53 [169]. The reduction in p53 activity enacted by E4orf6 is at least partially due to a complex formed by E4orf6 and Cul5-Elongin B-Elongin C E3 ubiquitin ligase that targets p53 for degradation [170]. E4orf6 can induce neddylation of Cul5, which encourages the nuclear localization of Cul5, where it can then interact with p53 [171]. Neddylation is the addition of a ubiquitin-like protein NEDD8 to target proteins, which can enact a multitude of functions from protein degradation to relocalization [172]. This complex appears to function optimally when the E4orf6 ligase complex includes E1B-55K [173]. In this complex, E1B-55K increases the amount of p53 that can interact with E4orf6 and the ligase [173]. E4orf3 can induce inhibitory H3K9 methylation of the promoters to which p53 would bind [174].

The ability of p53 to influence metabolism is well established [175]. The most notable changes enacted by p53 include downregulation of glycolysis and lipid biosynthesis and upregulation of mitochondrial respiration, beta-oxidation and the PPP [175]. However, whether p53 has a role in the metabolic changes that occur in context of HAdV infection remains to be conclusively identified.

\subsection{Regulation of 553 by HPV}

The HPV E6 oncoproteins, especially those of the most oncogenic types, HPV16 and HPV18, are responsible for modulating p53 activity by binding to and inducing the degradation of p53 [176-178] (Figure 2). The mechanism by which this occurs is thought to involve a complex between E6 and a host cell ubiquitin ligase, E6AP. [179]. When this complex binds p53, it is capable of inducing p53 degradation [179]. Interestingly, ubiquitination of E6 is required for this complex to degrade p53 successfully [179]. The efficiency of this complex appears to vary with HPV type [180]. Another mechanism utilized by E6 to contribute to the degradation of p53 involves nuclear export of a protein involved in heterochromatin formation, HP1 $\gamma$ [181]. HP1 $\gamma$ inhibits expression of UBE2L3, which assists E6-mediated degradation of p53 [181].

In contrast, the HPV E7 oncoprotein was reported to stabilize p53, which promoted apoptosis of infected cells [182]. E6 can contribute to the bypassing of this apoptotic induction by E7, which bears some resemblance to the opposing activities of HAdV E1A and E1B. However, it has been reported that E7 may inhibit p53 transcriptional activity [183]. 
One mechanism through which this occurs is by E7 inhibition of the p53-mediated DREAM pathway [184]. This implies that E7 could influence the changes in cellular metabolism that occur as a result of p53 inhibition. Neither of these results were generated in the context of HPV infection; however, differing cell lines and genetic vectors were used to deliver E7 into the cells. The study that found that E7 stabilizes p53 used a retroviral vector in primary IMR-90 fetal lung cells [182], while the studies that observed an inhibition of p53 activity by E7 used a plasmid vector and either osteosarcoma [183] or colon carcinoma cell lines. It is possible that these differences may explain why divergent effects of E7 on p53 were observed [184].

It is quite possible that HPV can upregulate glycolysis through the downregulation of p53 by the mechanisms discussed above. It would be interesting to see whether these and other metabolic hallmarks of HPV-induced cancers [185] are definitively driven by the differential expression of p53 when compared to corresponding HPV-negative cancers and non-cancerous tissues.

\subsection{Regulation of p53 by EBV}

EBV can influence the function of p53 through a variety of viral oncoproteins (Figure 2). These include the EBV latency protein EBNA3C, which has been noted to inhibit p53 DNA binding activity $[186,187]$. EBNA3C is thought to both block the transcriptional activity of p53 directly and encourage the degradation of p53 through the MDM2 protein as a result of this interaction [188]. EBNA3C also inhibits p53 by inducing the formation of a complex with the host cell DDX20 protein [189]. This complex prevents p53 binding to DNA and, in turn, reduces expression of the pro-apoptotic genes regulated by p53 [189]. Additionally, EBNA3C can interact with proteins that regulate $\mathrm{p} 53$, such as the positive regulators ING4 and ING5 [188]. EBNA3C forms a complex with either ING4 or ING5 and p53 that inhibits p53 activation by these two ING proteins [188].

LMP1 is another EBV latency protein and oncoprotein that can inhibit the activity of p53 [190-193]. There are reports of LMP1 achieving this through p53 ubiquitination at $\mathrm{K} 48$ or $\mathrm{K} 63$, the result of which is uncontrolled proliferation and an inhibition of apoptosis [194]. Interestingly, p53 also induces LMP1 expression, which is an example of a feedback loop in which the virus may be directly responding to the activity of tumor suppressor pathways [195].

Finally, the EBV immediate early lytic protein BZLF1 can inhibit p53 transactivation of its targets [196]. This is partially due to BZLF1-induced degradation of p53 through an ECS E3 ubiquitin ligase complex [197,198], a parallel with how E1B-55K and E4orf6 can also degrade 553 through an E3 ubiquitin ligase complex in HAdV infection.

In addition to protein-mediated effects, the EBV-encoded miR-BHRF1-1 miRNA can downregulate p53 expression in nasopharyngeal cancer cell lines by binding to the $3^{\prime}$ UTR of TP53 mRNA [199]. miR-BHRF1-1 is also associated with downregulation of TP53 in peripheral blood mononuclear cells from EBV-positive chronic lymphoid leukemia patients [200]. Another EBV-encoded miRNA that can target and inhibit p53 is mIR-BART53p [201]. mIR-BART5-3p can inhibit p53 in two ways. One way is through targeting the $3^{\prime}$ UTR of TP53 mRNA, which then leads to a measurable downregulation of expression of p53-regulated genes, including CDKN1A, BAX and FAS [201]. miR-BART5-3p can also contribute to the degradation of p53 protein [201].

It would be interesting to explore whether there is a direct link between the expression of each of these oncoproteins or viral miRNAs within EBV-positive cancer cell lines, the resulting expression of p53 and glycolytic upregulation or other associated metabolic changes.

\subsection{Regulation of p53 by KSHV}

The KSHV latency protein LANA can interact with p53 to repress cell death pathways mediated by p53 [202] (Figure 2). Additionally, LANA is a component of the $\mathrm{EC}_{5} \mathrm{~S}$ E3 ubiquitin ligase complex that targets p53 for degradation by polyubiquitination, thus 
limiting the activity of p53 by another mechanism [203]. The interaction of LANA with $\mathrm{EC}_{5} \mathrm{~S}$ could be mediated through its interactions with the complex components CUL5 and RBX1 [204]. Another host cell kinase, AURKA, is noted to increase the anti-p53 activities of LANA [205]. The inhibition of p53 by LANA can also cause increased chromosomal instability [206], perhaps contributing to the formation of KSHV-positive cancers. It is possible that the interaction of LANA with p53 is based on the stoichiometric availability of these two proteins within the infected cell [207]. It has also been suggested that the inhibitory interaction between LANA and p53 is enhanced by KSHV-encoded miRNAs [208].

The KSHV vIRF proteins can inhibit p53 function in KSHV-infected cells and models of B cell lymphomas. vIRF1 can associate with p53 and repress its transcriptional activity $[209,210]$. vIRF3 interaction with p53 also inhibits p53-mediated apoptotic pathways [211]. This interaction involves vIRF3 binding to the DNA binding domain of p53, which inhibits the phosphorylation of serines 15 and 20, which are key residues for the apoptotic functions of p53 [212]. vIRF3 also increases p53 ubiquitination, targeting it for proteasomal degradation [213]. Furthermore, vIRF3 inhibits SUMOylation of p53 by SUMO2 [214]. SUMOylation of p53 by SUMO2 is thought to enhance its activity $[39,215,216]$. This is in contrast to the SUMOylation of p53 by SUMO1 during HAdV infection as noted above, which has an inhibitory effect on p53 activity due to the tethering of p53 to E1B-55K [156]. vIRF4 can also inhibit p53 by increasing the stability of MDM2, which leads to an increase in p53 ubiquitination and degradation, thus inhibiting p53 pro-apoptotic activity [217].

Proteins involved in the lytic stage of KSHV infection can also inhibit p53 function. For example, the KSHV RTA protein, responsible for the switch between the latent and lytic cycles of KSHV replication [218], can repress both the transcriptional and apoptotic activities of $\mathrm{p} 53$ through an interaction with the CBP transcriptional coactivator [219]. Three other structural proteins expressed in the late lytic phase appear to inhibit p53 [220]. These are envelope glycoprotein H (ORF22), major capsid protein (ORF25) and large tegument protein deneddylase (ORF64) [220]. It is possible that these proteins serve to inhibit p53 during the entrance phase of infection in a newly infected cell rather than inhibiting p53 during the end of lytic KSHV replication [220].

There are two KSHV proteins that can augment p53 expression and stability. One protein, known as ORF10, increases the prevalence of the phosphorylation of p53 at serine 15, associated with increased p53 expression, and can reduce p53 ubiquitination [221]. The second KSHV protein that can stabilize p53 is vCYC, which stabilizes p53 through CDK9-mediated phosphorylation of p53 at serine 33 [222]. It is likely that the stabilization of p53 by these KSHV proteins mediates the transition to the lytic phase of the KSHV replication cycle [223].

While KSHV is reported to alter the activity of many metabolic pathways [224], including those that are regulated by p53 [225], whether the interaction between KSHV and p53 is the direct cause of any of these metabolic changes remains to be explored.

\section{Regulation of $\mathrm{pRb} / \mathrm{E} 2 \mathrm{~F}$ by DNA Tumor Virus Oncoproteins \\ 4.1. Regulation of $p R b / E 2 F$ by $H A d V$}

The HAdV oncoprotein that has a predominant interaction with $\mathrm{pRb}$ is E1A [226] (Figure 3). E1A can bind pRb directly to release E2F inhibition [227], thus greatly increasing the transcription of a variety of genes, including metabolism-related genes. This high affinity interaction is mediated by an LXCXE motif as well as a second site that mimics the portion of the E2F activation domain that normally interacts with $\mathrm{pRb}$ [228]. However, if E1A is bound to both $\mathrm{pRb}$ and $\mathrm{p} 300$, this can have an inhibitory effect on the transcription of other metabolism-related genes that are not transcribed by E2F due to the ability of this complex to lead to chromatin hypoacetylation and condensation [229]. Mechanistically, in this case, p300 linked to E1A may acetylate pRb in the complex, preventing inhibitory $\mathrm{pRb}$ phosphorylation [229]. Another mechanism by which E1A could inhibit $\mathrm{pRb}$ is by binding the LXCXE motif on pRb, which may sterically block access to a SUMOylation site 
on $\mathrm{pRb}$ [230]. SUMOylation of $\mathrm{pRb}$ is associated with relief of E2F repression [230]. The role of SUMOylation of $\mathrm{pRb}$ in the context of adenovirus infection is still not completely understood [231], and therefore, while SUMOylation of pRb may be important in uninfected cells, it is possible that HAdV can bypass this modification entirely.

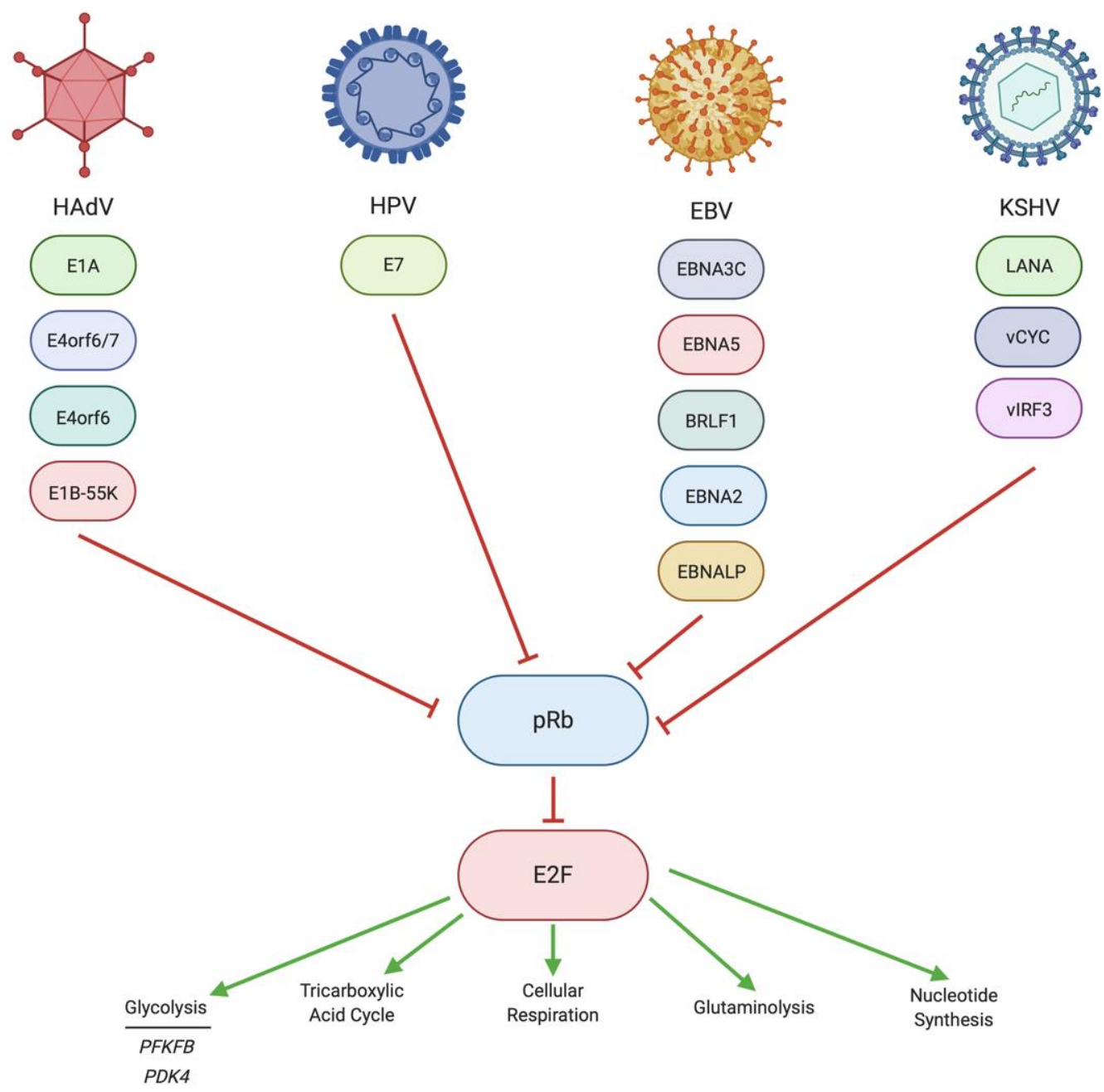

Figure 3. Regulation of $\mathrm{pRb} / \mathrm{E} 2 \mathrm{~F}$ by DNA tumor virus oncoproteins. Each of the DNA tumor viruses discussed in this review encodes proteins that can inhibit $\mathrm{pRb}$ suppression of E2F function. This allows for the upregulation of a wide variety of E2F targets. E2F, when activated, can alter the function of a wide variety of metabolic pathways. Created with BioRender.com.

Another HAdV protein, E4orf6/7, can displace pRb on E2F1, increasing transcriptional activation by E2F1 [232]. In addition to displacing pRb, E4orf6/7 was found to be involved in the nuclear localization of another E2F family member, E2F4 [233]. Likewise, E1A has been shown to activate E2F family members independently of $\mathrm{pRb}$ displacement. The $13 \mathrm{~S}$ isoform of E1A can interact with E2F4 through a complex containing DP1, which leads to increased transcriptional activity of E2F4 [234]. Interestingly, this function is limited to the $13 \mathrm{~S}$ isoform of E1A, and our study of the influence of E1A isoforms on metabolism showed that the $13 \mathrm{~S}$ isoform of E1A was responsible for regulating distinct aspects of cellular metabolism [60].

In another potentially redundant mechanism, the E3 ubiquitin ligase complex formed from E4orf6/E1B55K can also displace pRb from E2F family members, thereby permitting these transcription factors to transcribe their target genes [235]. The E4orf6/E1B-55k ligase complex can also enhance the E2F-releasing activities of E1A [236]. 
Studies examining the role of E1A-mediated release of E2F suppression by $\mathrm{pRb}$ on metabolism are limited. An analysis of published RNA-Seq datasets utilizing mutant E1A deficient for $\mathrm{pRb}$ binding [229] indicated that this interaction is indeed responsible for altering the expression of metabolism-related genes, particularly in nucleotide metabolism and glycerolipid metabolism, as reviewed by ourselves in [66].

\subsection{Regulation of $p R b / E 2 F$ by $H P V$}

The E7 oncoprotein of HPV is primarily responsible for influencing $\mathrm{pRb}$ (Figure 3), especially at early stages of infection [237-239]. E7 induces the degradation of pRb [240], but it is also capable of simply displacing $\mathrm{pRb}$ from $\mathrm{E} 2 \mathrm{~F}$ family members to induce DNA synthesis pathways [241]. E7 from high-risk HPV is especially effective at degrading $\mathrm{pRb}$ protein, without affecting RB1 mRNA expression [242]. However, like E1A, E7 inhibits SUMOylation of $\mathrm{pRb}$ [230]. As with E1A, SUMOylation of $\mathrm{pRb}$ is probably not required for the repression of $\mathrm{pRb}$ inhibitory functions by E7. Influencing $\mathrm{pRb}$ activity does not appear to be a major role for any of the other HPV-encoded proteins, including the E6 $\mathrm{HPV}$ oncoprotein. As with $\mathrm{p} 53$, the role of $\mathrm{pRb} / \mathrm{E} 2 \mathrm{~F}$ in regulating metabolism in the context of HPV infection or HPV-positive cancers has not been thoroughly elucidated. Any effects of $\mathrm{pRb} / \mathrm{E} 2 \mathrm{~F}$ on metabolism during HPV infection or in HPV-positive cancers, such as a theoretical upregulation of glutaminolysis or nucleotide metabolism, have been deduced based on studies performed on $\mathrm{pRb} / \mathrm{E} 2 \mathrm{~F}$ in isolation and remain to be conclusively demonstrated in the context of HPV infection and HPV-positive cancers.

\subsection{Regulation of $p R b / E 2 F$ by $E B V$}

A variety of EBV-encoded viral proteins are capable of inducing E2F expression or activity. One example is the immediate-early EBV protein BRLF1, which induces expression of E2F itself $[243,244]$. Some of the EBV-encoded EBNA proteins are also capable of binding $\mathrm{pRb}$, thus freeing E2F activity. Indeed, both EBNA3C [245] and EBNA5 [246] can bind $\mathrm{pRb}$ to induce E2F-dependent gene expression (Figure 3). Additionally, EBNA3C can bind E2F1 directly at the N-terminal region of E2F1 to block the pro-apoptotic activities of E2F1, which still allows the proliferation-promoting activities of E2F1 to occur [247]. Another mechanism by which EBNA3C regulates the transcription activities of E2F1 is through a complex formed between EBNA3C, E2F1 and another E2F family member, E2F6 [248]. This serves to further repress E2F1-mediated expression of genes that inhibit abnormal proliferation [248]. It also appears that interactions between either EBNA2, EBNA3C or EBNALP and $\mathrm{E} 2 \mathrm{~F} / \mathrm{pRb} / \mathrm{HDAC}$ complexes may also be involved in regulating the expression of anti-proliferative genes [249].

The $\mathrm{pRb} / \mathrm{E} 2 \mathrm{~F}$ complex is responsible for regulating a wide range of metabolic processes, including glycolysis, central carbon metabolism, redox metabolism and mitochondrial biogenesis $[41,250]$. However, how EBV interacts with $\mathrm{pRb} / \mathrm{E} 2 \mathrm{~F}$ to directly influence these metabolic pathways still remains generally speculative based upon the functions of $\mathrm{pRb} / \mathrm{E} 2 \mathrm{~F}$ alone [251].

\subsection{Regulation of $p R b / E 2 F$ by $K S H V$}

Unlike its multifaceted interactions with MYC and p53, only a few KSHV-encoded latent proteins appear to interact with $\mathrm{pRb}$ (Figure 3). LANA targets $\mathrm{pRb}$, freeing E2F to activate transcription [252]. $\mathrm{vCYC}$ can promote the phosphorylation of $\mathrm{pRb}$, leading to its inactivation and, again, allowing E2F-mediated transcription to occur [253]. In this case, phosphorylation of $\mathrm{pRb}$ is mediated by cellular CDK6, which is activated by vCYC [253]. Finally, vIRF3 can bind to $\mathrm{pRb}$ and contains an LXCXE motif similar to those found in HAdV E1A and HPV E7 [254]. However, this motif is not required for $\mathrm{pRb}$ binding by vIRF3 [254]. Instead, the LXCXE motif is required for vIRF3 inhibition of pRb SUMOylation, which blocks the tumor suppressor functions of $\mathrm{pRb}$ [254].

Like HPV and EBV, studies directly linking the effects of KSHV on the pRb/E2F complex and the resulting effects of that interaction on metabolism are limited. It is well 
established that KSHV can upregulate glycolysis, glutaminolysis and fatty acid synthesis while contributing to the downregulation of oxidative phosphorylation during KSHV infection [255]. Despite this, it has not been conclusively shown which of these pathways are indeed regulated by an interaction between KSHV and pRb/E2F [251].

\section{Conclusions}

This review outlined how four different DNA tumor viruses-HAdV, HPV, EBV and KSHV_all target three specific host cell regulatory proteins known to influence host cell metabolism. The importance of these proteins, namely MYC, p53 and pRb/E2F, in promoting cell growth and oncogenesis overshadows their ability to regulate host cell metabolism. Nevertheless, their important role in controlling cell metabolism should not be overlooked. For example, in MYC-driven cancers, targeting of certain glycolytic enzymes upregulated by MYC represented vulnerabilities that are not present in cells with non-dysregulated levels of MYC and are potentially targetable for treatment $[256,257]$. It is possible that cancers caused by DNA tumor viruses exhibit similar metabolic alterations, unwittingly creating novel vulnerabilities in the infected cells [258,259]. Targeting a viral oncoprotein, its cellular regulatory protein effector or the resulting upregulated metabolic pathway could be interesting avenues in which to explore synthetic lethality for the treatment of viral diseases or the cancers associated with DNA tumor virus infections [258].

Author Contributions: Writing—original draft preparation, M.A.P.; writing—review and editing, J.S.M. All authors have read and agreed to the published version of the manuscript.

Funding: This research was funded by grants provided by the Canadian Institutes of Health Research, grant numbers MOP\#148689 and PJT\#173496, awarded to J.S.M.

Acknowledgments: M.A.P. was supported by a studentship from the Natural Sciences and Engineering Research Council of Canada and a studentship from the Western University Schulich School of Medicine and Dentistry.

Conflicts of Interest: The authors declare no conflict of interest.

\section{References}

1. Edmunds, L.R.; Sharma, L.; Kang, A.; Lu, J.; Vockley, J.; Basu, S.; Uppala, R.; Goetzman, E.S.; Beck, M.E.; Scott, D.; et al. c-MYC programs fatty acid metabolism and dictates acetyl-CoA abundance and fate. J. Biol. Chem. 2014, 289, 25382-25392. [CrossRef]

2. Shim, H.; Dolde, C.; Lewis, B.C.; Wu, C.S.; Dang, G.; Jungmann, R.A.; Dalla-Favera, R.; Dang, C.V. c-MYC transactivation of LDH-A: Implications for tumor metabolism and growth. Proc. Natl. Acad. Sci. USA 1997, 94, 6658-6663. [CrossRef]

3. Wang, R.; Dillon, C.P.; Shi, L.Z.; Milasta, S.; Carter, R.; Finkelstein, D.; McCormick, L.L.; Fitzgerald, P.; Chi, H.; Munger, J.; et al. The Transcription Factor MYC Controls Metabolic Reprogramming upon T Lymphocyte Activation. Immunity 2011, 35, 871-882. [CrossRef]

4. Liu, Y.C.; Li, F.; Handler, J.; Huang, C.R.L.; Xiang, Y.; Neretti, N.; Sedivy, J.M.; Zeller, K.I.; Dang, C.V. Global regulation of nucleotide biosynthetic genes by c-MYC. PLoS ONE 2008, 3, e2722. [CrossRef]

5. Osthus, R.C.; Shim, H.; Kim, S.; Li, Q.; Reddy, R.; Mukherjee, M.; Xu, Y.; Wonsey, D.; Lee, L.A.; Dang, C.V. Deregulation of glucose transporter 1 and glycolytic gene expression by c-MYC. J. Biol. Chem. 2000, 275, 21797-21800. [CrossRef]

6. Zhao, X.; Petrashen, A.P.; Sanders, J.A.; Peterson, A.L.; Sedivy, J.M. SLC1A5 glutamine transporter is a target of MYC and mediates reduced mTORC1 signaling and increased fatty acid oxidation in long-lived MYC hypomorphic mice. Aging Cell 2019, 18, 1-6. [CrossRef] [PubMed]

7. Morrish, F.; Isern, N.; Sadilek, M.; Jeffrey, M.; Hockenbery, D.M. C-MYC activates multiple metabolic networks to generate substrates for cell-cycle entry. Oncogene 2009, 28, 2485-2491. [CrossRef]

8. Mannava, S.; Grachtchouk, V.; Wheeler, L.J.; Im, M.; Zhuang, D.; Slavina, E.G.; Mathews, C.K.; Shewach, D.S.; Nikiforov, M.A. Direct role of nucleotide metabolism in C-MYC-dependent proliferation of melanoma cells. Cell Cycle 2008, 7, 2392-2400. [CrossRef]

9. Morrish, F.; Noonan, J.; Perez-Olsen, C.; Gafken, P.R.; Fitzgibbon, M.; Kelleher, J.; VanGilst, M.; Hockenbery, D. MYC-dependent mitochondrial generation of acetyl-CoA contributes to fatty acid biosynthesis and histone acetylation during cell cycle entry. $J$. Biol. Chem. 2010, 285, 36267-36274. [CrossRef]

10. Graves, J.A.; Wang, Y.; Sims-Lucas, S.; Cherok, E.; Rothermund, K.; Branca, M.F.; Elster, J.; Beer-Stolz, D.; van Houten, B.; Vockley, J.; et al. Mitochondrial structure, function and dynamics are temporally controlled by c-MYC. PLoS ONE 2012, 7, e37699. [CrossRef] 
11. Kalkat, M.; De Melo, J.; Hickman, K.A.; Lourenco, C.; Redel, C.; Resetca, D.; Tamachi, A.; Tu, W.B.; Penn, L.Z. MYC deregulation in primary human cancers. Genes 2017, 8, 151. [CrossRef]

12. Sears, R.; Nuckolls, F.; Haura, E.; Taya, Y.; Tamai, K.; Nevins, J.R. Multiple Ras-dependent phosphorylation pathways regulate MYC protein stability. Genes Dev. 2000, 14, 2501-2514. [CrossRef]

13. Zhu, J.; Blenis, J.; Yuan, J. Activation of PI3K/Akt and MAPK pathways regulates MYC-mediated transcription by phosphorylating and promoting the degradation of Mad1. Proc. Natl. Acad. Sci. USA 2008, 105, 6584-6589. [CrossRef] [PubMed]

14. Yagi, K.; Furuhashi, M.; Aoki, H.; Goto, D.; Kuwano, H.; Sugamura, K.; Miyazono, K.; Kato, M. c-MYC is a downstream target of the Smad pathway. J. Biol. Chem. 2002, 277, 854-861. [CrossRef]

15. Lord, J.D.; McIntosh, B.C.; Greenberg, P.D.; Nelson, B.H. The IL-2 Receptor Promotes Lymphocyte Proliferation and Induction of the c- MYC, bcl-2, and bcl-x Genes Through the trans- Activation Domain of Stat5. J. Immunol. 2000, 164, 2533-2541. [CrossRef] [PubMed]

16. Dubik, D.; Shiu, R.P. Mechanism of estrogen activation of c-MYC oncogene expression. Oncogene 1992, 7, 1587-1594.

17. Yochum, G.S. Multiple wnt/ $\$$-catenin responsive enhancers align with the MYC promoter through long-range chromatin loops. PLOS ONE 2011, 6, e18966. [CrossRef]

18. Hnisz, D.; Abraham, B.J.; Lee, T.I.; Lau, A.; Saint-André, V.; Sigova, A.A.; Hoke, H.A.; Young, R.A. Super-enhancers in the control of cell identity and disease. Cell 2013, 155, 934. [CrossRef]

19. Smith, M.L.; Chen, I.T.; Zhan, Q.; O'Connor, P.M.; Fornace, A.J. Involvement of the p53 tumor suppressor in repair of u.v.-type DNA damage. Oncogene 1995, 10, 1053-1059. [PubMed]

20. Chandel, N.S.; Vander Heiden, M.G.; Thompson, C.B.; Schumacker, P.T. Redox regulation of p53 during hypoxia. Oncogene 2000, 19, 3840-3848. [CrossRef] [PubMed]

21. Wei, X.; Xu, H.; Kufe, D. Human MUC1 oncoprotein regulates p53-responsive gene transcription in the genotoxic stress response. Cancer Cell 2005, 7, 167-178. [CrossRef]

22. Hafner, A.; Bulyk, M.L.; Jambhekar, A.; Lahav, G. The multiple mechanisms that regulate p53 activity and cell fate. Nat. Rev. Mol. Cell Biol. 2019, 20, 199-210. [CrossRef] [PubMed]

23. Coates, P.J.; Save, V.; Ansari, B.; Hall, P.A. Demonstration of DNA damage/repair in individual cells using in situ end labelling: Association of p53 with sites of DNA damage. J. Pathol. 1995, 176, 19-26. [CrossRef]

24. Yonish-Rouach, E.; Resnftzky, D.; Lotem, J.; Sachs, L.; Kimchi, A.; Oren, M. Wild-type p53 induces apoptosis of myeloid leukaemic cells that is inhibited by interleukin-6. Nature 1991, 352, 345-347. [CrossRef]

25. Jones, R.G.; Plas, D.R.; Kubek, S.; Buzzai, M.; Mu, J.; Xu, Y.; Birnbaum, M.J.; Thompson, C.B. AMP-activated protein kinase induces a p53-dependent metabolic checkpoint. Mol. Cell 2005, 18, 283-293. [CrossRef]

26. Matoba, S.; Kang, J.-G.; Patino, W.D.; Wragg, A.; Boehm, M.; Gavrilova, O.; Hurley, P.J.; Bunz, F.; Hwang, P.M. p53 Regulates Mitochondrial Respiration. Science 2006, 312, 1650-1653. [CrossRef] [PubMed]

27. Livingstone, L.R.; White, A.; Sprouse, J.; Livanos, E.; Jacks, T.; Tlsty, T.D. Altered cell cycle arrest and gene amplification potential accompany loss of wild-type p53. Cell 1992, 70, 923-935. [CrossRef]

28. Haupt, Y.; Mayat, R.; Kazazt, A.; Orent, M. Mdm2 promotes the rapid degradation of p53. Nature 1997, 387, 296-299. [CrossRef]

29. Kapoor, M.; Lozano, G. Functional activation of p53 via phosphorylation following DNA damage by UV but not $\gamma$ radiation. Proc. Natl. Acad. Sci. USA 1998, 95, 2834-2837. [CrossRef]

30. Tang, Q.; Su, Z.; Gu, W.; Rustgi, A.K. Mutant p53 on the Path to Metastasis. Trends Cancer 2020, 6, 62-73. [CrossRef]

31. Schwartzenberg-Bar-Yoseph, F.; Armoni, M.; Karnieli, E. The Tumor Suppressor p53 Down-Regulates Glucose Transporters GLUT1 and GLUT4 Gene Expression. Cancer Res. 2004, 64, 2627-2633. [CrossRef]

32. Kondoh, H.; Lleonart, M.E.; Gil, J.; Wang, J.; Degan, P.; Peters, G.; Martinez, D.; Carnero, A.; Beach, D. Glycolytic enzymes can modulate cellular life span. Cancer Res. 2005, 65, 177-185.

33. Bensaad, K.; Tsuruta, A.; Selak, M.A.; Vidal, M.N.C.; Nakano, K.; Bartrons, R.; Gottlieb, E.; Vousden, K.H. TIGAR, a p53-Inducible Regulator of Glycolysis and Apoptosis. Cell 2006, 126, 107-120. [CrossRef]

34. Bellacchio, E.; Paggi, M.G. Understanding the targeting of the RB family proteins by viral oncoproteins to defeat their oncogenic machinery. J. Cell. Physiol. 2013, 228, 285-291. [CrossRef] [PubMed]

35. Sdek, P.; Ying, H.; Chang, D.L.F.; Qiu, W.; Zheng, H.; Touitou, R.; Allday, M.J.; Jim Xiao, Z.X. MDM2 promotes proteasomedependent ubiquitin-independent degradation of retinoblastoma protein. Mol. Cell 2005, 20, 699-708. [CrossRef]

36. Medema, R.H.; Herrera, R.E.; Lam, F.; Weinberg, R.A. Growth suppression by p16ink4 requires functional retinoblastoma protein. Proc. Natl. Acad. Sci. USA 1995, 92, 6289-6293. [CrossRef] [PubMed]

37. DeCaprio, J.A.; Ludlow, J.W.; Lynch, D.; Furukawa, Y.; Griffin, J.; Piwnica-Worms, H.; Huang, C.M.; Livingston, D.M. The product of the retinoblastoma susceptibility gene has properties of a cell cycle regulatory element. Cell 1989, 58, 1085-1095. [CrossRef]

38. Chan, H.M.; Krstic-Demonacos, M.; Smith, L.; Demonacos, C.; La Thangue, N.B. Acetylation control of the retinoblastoma tumour-suppressor protein. Nat. Cell Biol. 2001, 3, 667-674. [CrossRef] [PubMed]

39. Li, T.; Santockyte, R.; Shen, R.F.; Tekle, E.; Wang, G.; Yang, D.C.H.; Chock, P.B. Expression of SUMO-2/3 induced senescence through p53- and pRB-mediated pathways. J. Biol. Chem. 2006, 281, 36221-36227. [CrossRef]

40. Bhattacharya, S.; Ghosh, M.K. HAUSP, a novel deubiquitinase for Rb - MDM2 the critical regulator. FEBS J. 2014, 281, 3061-3078. [CrossRef] 
41. Nicolay, B.N.; Dyson, N.J. The multiple connections between pRB and cell metabolism. Curr. Opin. Cell Biol. 2013, $25,735-740$. [CrossRef]

42. Darville, M.I.; Antoine, I.V.; Mertens-Strijthagen, J.R.; Dupriez, V.J.; Rousseau, G.G. An E2F-dependent late-serum-response promoter in a gene that controls glycolysis. Oncogene 1995, 11, 1509-1517.

43. De Mattos, S.F.; Lam, E.W.F.; Tauler, A. An E2F-binding site mediates the activation of the proliferative isoform of 6-phosphofructo2-kinase/fructose-2,6-bisphosphatase by phosphatidylinositol 3-kinase. Biochem. J. 2002, 368, 283-291. [CrossRef]

44. Hsieh, M.C.F.; Das, D.; Sambandam, N.; Zhang, M.Q.; Nahlé, Z. Regulation of the PDK4 isozyme by the Rb-E2F1 complex. J. Biol. Chem. 2008, 283, 27410-27417. [CrossRef]

45. Nicolay, B.N.; Gameiro, P.A.; Tschöp, K.; Korenjak, M.; Heilmann, A.M.; Asara, J.M.; Stephanopoulos, G.; Iliopoulos, O.; Dyson, N.J. Loss of RBF1 changes glutamine catabolism. Genes Dev. 2013, 27, 182-196. [CrossRef]

46. Reynolds, M.R.; Lane, A.N.; Robertson, B.; Kemp, S.; Liu, Y.; Hill, B.G.; Dean, D.C.; Clem, B.F. Control of glutamine metabolism by the tumor suppressor Rb. Oncogene 2014, 33, 556-566. [CrossRef] [PubMed]

47. DeGregori, J.; Kowalik, T.; Nevins, J.R. Cellular targets for activation by the E2F1 transcription factor include DNA synthesis- and G1/S-regulatory genes. Mol. Cell. Biol. 1995, 15, 4215-4224. [CrossRef] [PubMed]

48. Berk, A.J. Functions of adenovirus E1A. Cancer Surv. 1986, 5, 367-387.

49. Barker, D.D.; Berk, A.J. Adenovirus proteins from both E1B reading frames are required for transformation of rodent cells by viral infection and DNA transfection. Virology 1987, 156, 107-121. [CrossRef]

50. Javier, R.T. Adenovirus type 9 E4 open reading frame 1 encodes a transforming protein required for the production of mammary tumors in rats. J. Virol. 1994, 68, 3917-3924. [CrossRef] [PubMed]

51. Nevels, M.; Rubenwolf, S.; Spruss, T.; Wolf, H.; Dobner, T. Two Distinct Activities Contribute to the Oncogenic Potential of the Adenovirus Type 5 E4orf6 Protein. J. Virol. 2000, 74, 5168-5181. [CrossRef]

52. Valdés, A.; Zhao, H.; Pettersson, U.; Lind, S.B. Time-resolved proteomics of adenovirus infected cells. PLoS ONE 2018, 13, 1-23. [CrossRef] [PubMed]

53. Thai, M.; Graham, N.A.; Braas, D.; Nehil, M.; Komisopoulou, E.; Kurdistani, S.K.; McCormick, F.; Graeber, T.G.; Christofk, H.R. Adenovirus E4ORF1-induced MYC activation promotes host cell anabolic glucose metabolism and virus replication. Cell Metab. 2014, 19, 694-701. [CrossRef]

54. Thai, M.; Thaker, S.K.; Feng, J.; Du, Y.; Hu, H.; Ting Wu, T.; Graeber, T.G.; Braas, D.; Christofk, H.R. MYC-induced reprogramming of glutamine catabolism supports optimal virus replication. Nat. Commun. 2015, 6, 8873. [CrossRef] [PubMed]

55. Kong, K.; Kumar, M.; Taruishi, M.; Javier, R.T. Adenovirus E4-ORF1 Dysregulates Epidermal Growth Factor and Insulin/InsulinLike Growth Factor Receptors To Mediate Constitutive MYC Expression. J. Virol. 2015, 89, 10774-10785. [CrossRef] [PubMed]

56. Zhao, L.; Loewenstein, P.M.; Green, M. Enhanced MYC association with the NuA4 histone acetyltransferase complex mediated by the adenovirus E1A N-terminal domain activates a subset of MYC target genes highly expressed in cancer cells. Genes Cancer 2017, 8, 752. [CrossRef]

57. Löhr, K.; Hartmann, O.; Schäfer, H.; Dobbelstein, M. Mutual Interference of Adenovirus Infection and MYC Expression. J. Virol. 2003, 77, 7936-7944. [CrossRef] [PubMed]

58. Tworkowski, K.A.; Chakraborty, A.A.; Samuelson, A.V.; Seger, Y.R.; Narita, M.; Hannon, G.J.; Lowe, S.W.; Tansey, W.P. Adenovirus E1A targets p400 to induce the cellular oncoprotein MYC. Proc. Natl. Acad. Sci. USA 2008, 105, 6103-6108. [CrossRef]

59. Kadeppagari, R.-K.; Sankar, N.; Thimmapaya, B. Adenovirus Transforming Protein E1A Induces c-MYC in Quiescent Cells by a Novel Mechanism. J. Virol. 2009, 83, 4810-4822. [CrossRef] [PubMed]

60. Prusinkiewicz, M.A.; Tu, J.; Dodge, M.J.; MacNeil, K.M.; Radko-Juettner, S.; Fonseca, G.J.; Pelka, P.; Mymryk, J.S. Differential effects of human adenovirus E1A protein isoforms on aerobic glycolysis in A549 human lung epithelial cells. Viruses 2020, 12, 610 [CrossRef] [PubMed]

61. Zhao, L.-J.; Loewenstein, P.M.; Green, M. The adenoviral E1A N-terminal domain represses MYC transcription in human cancer cells by targeting both p300 and TRRAP and inhibiting MYC promoter acetylation of H3K18 and H4K16. Genes Cancer 2016, 7, 98-109. [CrossRef]

62. Higashino, F.; Aoyagi, M.; Takahashi, A.; Ishino, M.; Taoka, M.; Isobe, T.; Kobayashi, M.; Totsuka, Y.; Kohgo, T.; Shindoh, M. Adenovirus E4orf6 targets pp32/LANP to control the fate of ARE-containing mRNAs by perturbing the CRM1-dependent mechanism. J. Cell Biol. 2005, 170, 15-20. [CrossRef] [PubMed]

63. Ben-Israel, H.; Sharf, R.; Rechavi, G.; Kleinberger, T. Adenovirus E4orf4 Protein Downregulates MYC Expression through Interaction with the PP2A-B55 Subunit. J. Virol. 2008, 82, 9381-9388. [CrossRef] [PubMed]

64. Graham, F.L.; Smiley, J.; Russell, W.C.; Nairn, R. Characteristics of a Human Cell Line Transformed by DNA from Human Adenovirus Type 5. J. Gen. Virol 1977, 36, 59-66. [CrossRef]

65. Arnold, H.K.; Sears, R.C. Protein Phosphatase 2A Regulatory Subunit B56 $\alpha$ Associates with c-MYC and Negatively Regulates c-MYC Accumulation. Mol. Cell. Biol. 2006, 26, 2832-2844. [CrossRef]

66. Prusinkiewicz, M.A.; Mymryk, J.S. Metabolic Reprogramming of the Host Cell by Human Adenovirus Infection. Viruses 2019, 11, 141. [CrossRef] [PubMed]

67. Peta, E.; Sinigaglia, A.; Masi, G.; Di Camillo, B.; Grassi, A.; Trevisan, M.; Messa, L.; Loregian, A.; Manfrin, E.; Brunelli, M.; et al. HPV16 E6 and E7 upregulate the histone lysine demethylase KDM2B through the c-MYC/miR-146a-5p axys. Oncogene 2018, 37, 1654-1668. [CrossRef] 
68. Zhang, Y.; Dakic, A.; Chen, R.; Dai, Y.; Schlegel, R.; Liu, X. Direct HPV E6/MYC interactions induce histone modifications, Pol II phosphorylation, and hTERT promoter activation. Oncotarget 2017, 8, 96323-96339. [CrossRef]

69. Veldman, T.; Liu, X.; Yuan, H.; Schlegel, R. Human papillomavirus E6 and MYC proteins associate in vivo and bind to and cooperatively activate the telomerase reverse transcriptase promoter. Proc. Natl. Acad. Sci. USA 2003, 100, 8211-8216. [CrossRef]

70. Oh, S.T.; Kyo, S.; Laimins, L.A. Telomerase Activation by Human Papillomavirus Type 16 E6 Protein: Induction of Human Telomerase Reverse Transcriptase Expression through MYC and GC-Rich Sp1 Binding Sites. J. Virol. 2001, 75, 5559-5566. [CrossRef]

71. Gross-Mesilaty, S.; Reinstein, E.; Bercovich, B.; Tobias, K.E.; Schwartz, A.L.; Kahana, C.; Ciechanover, A. Basal and human papillomavirus E6 oncoprotein-induced degradation of MYC proteins by the ubiquitin pathway. Proc. Natl. Acad. Sci. USA 1998, 95, 8058-8063. [CrossRef]

72. Liu, X.; Disbrow, G.L.; Yuan, H.; Tomaić, V.; Schlegel, R. MYC and Human Papillomavirus Type 16 E7 Genes Cooperate To Immortalize Human Keratinocytes. J. Virol. 2007, 81, 12689-12695. [CrossRef] [PubMed]

73. Wang, Y.W.; Chang, H.S.; Lin, C.H.; Yu, W.C.Y. HPV-18 E7 conjugates to c-MYC and mediates its transcriptional activity. Int. J. Biochem. Cell Biol. 2007, 39, 402-412. [CrossRef]

74. Strickland, S.W.; Vande Pol, S. The Human Papillomavirus 16 E7 Oncoprotein Attenuates AKT Signaling To Promote Internal Ribosome Entry Site-Dependent Translation and Expression of c-MYC. J. Virol. 2016, 90, 5611-5621. [CrossRef]

75. Morandell, D.; Kaiser, A.; Herold, S.; Rostek, U.; Lechner, S.; Mitterberger, M.C.; Jansen-Dürr, P.; Eilers, M.; Zwerschke, W. The human papillomavirus type 16 E7 oncoprotein targets MYC-interacting zinc-finger protein-1. Virology 2012, 422, 242-253. [CrossRef]

76. Bhattacharya, N.; Roy, A.; Roy, B.; Roychoudhury, S.; Panda, C.K. MYC gene amplification reveals clinical association with head and neck squamous cell carcinoma in Indian patients. J. Oral Pathol. Med. 2009, 38, 759-763. [CrossRef]

77. Bhattacharya, N.; Sabbir, M.G.; Roy, A.; Dam, A.; Roychoudhury, S.; Panda, C.K. Approximately 580 Kb surrounding the MYC gene is amplified in head and neck squamous cell carcinoma of Indian patients. Pathol. Res. Pract. 2005, 201, 691-697. [CrossRef] [PubMed]

78. Kim, S.H.; Koo, B.S.; Kang, S.; Park, K.; Kim, H.; Lee, K.R.; Lee, M.J.; Kim, J.M.; Choi, E.C.; Cho, N.H. HPV integration begins in the tonsillar crypt and leads to the alteration of p16, EGFR and c-MYC during tumor formation. Int. J. Cancer 2007, 120, 1418-1425. [CrossRef] [PubMed]

79. Arizmendi-Izazaga, A.; Navarro-Tito, N.; Jiménez-Wences, H.; Mendoza-Catalán, M.A.; Martínez-Carrillo, D.N.; Zacapala-Gómez, A.E.; Olea-Flores, M.; Dircio-Maldonado, R.; Torres-Rojas, F.I.; Soto-Flores, D.G.; et al. Metabolic Reprogramming in Cancer: Role of HPV 16 Variants. Pathogens 2021, 10, 347. [CrossRef]

80. Dalla-Favera, R.; Bregni, M.; Erikson, J.; Patterson, D.; Gallo, R.C.; Croce, C.M. Human c-MYC onc gene is located on the region of chromosome 8 that is translocated in Burkitt lymphoma cells. Proc. Natl. Acad. Sci. USA 1982, 79, 7824-7827. [CrossRef] [PubMed]

81. Allday, M.J. How does Epstein-Barr virus (EBV) complement the activation of MYC in the pathogenesis of Burkitt's lymphoma? Semin. Cancer Biol. 2009, 19, 366-376. [CrossRef]

82. Fitzsimmons, L.; Kelly, G.L. EBV and Apoptosis: The Viral Master Regulator of Cell Fate? Viruses 2017, 9, 339. [CrossRef] [PubMed]

83. Kaiser, C.; Laux, G.; Eick, D.; Jochner, N.; Bornkamm, G.W.; Kempkes, B. The Proto-Oncogene c-MYC Is a Direct Target Gene of Epstein-Barr Virus Nuclear Antigen 2. J. Virol. 1999, 73, 4481-4484. [CrossRef]

84. Zhao, B.; Zou, J.; Wang, H.; Johannsen, E.; Peng, C.W.; Quackenbush, J.; Mar, J.C.; Morton, C.C.; Freedman, M.L.; Blacklow, S.C.; et al. Epstein-Barr virus exploits intrinsic B-lymphocyte transcription programs to achieve immortal cell growth. Proc. Natl. Acad. Sci. USA 2011, 108, 14902-14907. [CrossRef] [PubMed]

85. Wood, C.D.; Veenstra, H.; Khasnis, S.; Gunnell, A.; Webb, H.M.; Shannon-Lowe, C.; Andrews, S.; Osborne, C.S.; West, M.J. MYC activation and BCL2L11 silencing by a tumour virus through the large-scale reconfiguration of enhancer-promoter hubs. Elife 2016, 5, 1-23. [CrossRef] [PubMed]

86. Zhou, H.; Schmidt, S.C.S.; Jiang, S.; Willox, B.; Bernhardt, K.; Liang, J.; Johannsen, E.C.; Kharchenko, P.; Gewurz, B.E.; Kieff, E.; et al. Epstein-Barr Virus Oncoprotein Super-enhancers Control B Cell Growth. Cell Host Microbe 2015, 17, 205-216. [CrossRef]

87. Liang, J.; Zhou, H.; Gerdt, C.; Tan, M.; Colson, T.; Kaye, K.M.; Kieff, E.; Zhao, B. Epstein-Barr virus super-enhancer eRNAs are essential for MYC oncogene expression and lymphoblast proliferation. Proc. Natl. Acad. Sci. USA 2016, 113, 14121-14126. [CrossRef]

88. Wang, L.W.; Shen, H.; Nobre, L.; Ersing, I.; Paulo, J.A.; Trudeau, S.; Wang, Z.; Smith, N.A.; Ma, Y.; Reinstadler, B.; et al. Epstein-Barr-Virus-Induced One-Carbon Metabolism Drives B Cell Transformation. Cell Metab. 2019, 30, 539-555.e11. [CrossRef]

89. Wang, L.W.; Wang, Z.; Ersing, I.; Nobre, L.; Guo, R.; Jiang, S.; Trudeau, S.; Zhao, B.; Weekes, M.P.; Gewurz, B.E. Epstein-barr virus subverts mevalonate and fatty acid pathways to promote infected B-cell proliferation and survival. PLoS Pathog. 2019, 15, e1008030. [CrossRef]

90. Magon, K.L.; Parish, J.L. From infection to cancer: How DNA tumour viruses alter host cell central carbon and lipid metabolism. Open Biol. 2021, 11, 210004. [CrossRef]

91. Jiang, S.; Zhou, H.; Liang, J.; Gerdt, C.; Wang, C.; Ke, L.; Schmidt, S.C.S.; Narita, Y.; Ma, Y.; Wang, S.; et al. The Epstein-Barr Virus Regulome in Lymphoblastoid Cells. Cell Host Microbe 2017, 22, 561-573.e4. [CrossRef] [PubMed] 
92. Bajaj, B.G.; Murakami, M.; Cai, Q.; Verma, S.C.; Lan, K.; Robertson, E.S. Epstein-Barr Virus Nuclear Antigen 3C Interacts with and Enhances the Stability of the c-MYC Oncoprotein. J. Virol. 2008, 82, 4082-4090. [CrossRef] [PubMed]

93. Styles, C.T.; Paschos, K.; White, R.E.; Farrell, P.J. The cooperative functions of the EBNA3 proteins are central to EBV persistence and latency. Pathogens 2018, 7, 31. [CrossRef] [PubMed]

94. Paschos, K.; Smith, P.; Anderton, E.; Middeldorp, J.M.; White, R.E.; Allday, M.J. Epstein-Barr virus latency in B cells leads to epigenetic repression and CpG methylation of the tumour suppressor gene Bim. PLoS Pathog. 2009, 5, e1000492. [CrossRef]

95. Anderton, E.; Yee, J.; Smith, P.; Crook, T.; White, R.E.; Allday, M.J. Two Epstein-Barr virus (EBV) oncoproteins cooperate to repress expression of the proapoptotic tumour-suppressor Bim: Clues to the pathogenesis of Burkitt's lymphoma. Oncogene 2008, 27, 421-433. [CrossRef] [PubMed]

96. Dirmeier, U.; Hoffmann, R.; Kilger, E.; Schultheiss, U.; Briseño, C.; Gires, O.; Kieser, A.; Eick, D.; Sugden, B.; Hammerschmidt, W. Latent membrane protein 1 of Epstein-Barr virus coordinately regulates proliferation with control of apoptosis. Oncogene 2005, 24, 1711-1717. [CrossRef]

97. Chen, H.; Hutt-Fletcher, L.; Cao, L.; Hayward, S.D. A Positive Autoregulatory Loop of LMP1 Expression and STAT Activation in Epithelial Cells Latently Infected with Epstein-Barr Virus. J. Virol. 2003, 77, 4139-4148. [CrossRef]

98. Kwok Fung Lo, A.; Wai Lo, K.; Tsao, S.W.; Wong, H.L.; Ying Hui, J.W.; To, K.F.; Hayward, S.D.; Chui, Y.L.; Lau, Y.L.; Takada, K.; et al. Epstein-Barr Virus Infection Alters Cellular Signal Cascades in Human Nasopharyngeal Epithelial Cells. Neoplasia 2006, 8, 173-180. [CrossRef] [PubMed]

99. Shi, F.; He, Y.; Li, J.; Tang, M.; Li, Y.; Xie, L.; Zhao, L.; Hu, J.; Luo, X.; Zhou, M.; et al. Wild-type IDH2 contributes to Epstein-Barr virus-dependent metabolic alterations and tumorigenesis. Mol. Metab. 2020, 36, 1-11. [CrossRef]

100. Cao, Y.; Xie, L.; Shi, F.; Tang, M.; Li, Y.; Hu, J.; Zhao, L.; Zhao, L.; Yu, X.; Luo, X.; et al. Targeting the signaling in Epstein-Barr virus-associated diseases: Mechanism, regulation, and clinical study. Signal Transduct. Target. Ther. 2021, 6, 1-33.

101. Xiao, L.; Hu, Z.Y.; Dong, X.; Tan, Z.; Li, W.; Tang, M.; Chen, L.; Yang, L.; Tao, Y.; Jiang, Y.; et al. Targeting Epstein-Barr virus oncoprotein LMP1-mediated glycolysis sensitizes nasopharyngeal carcinoma to radiation therapy. Oncogene 2014, 33, 4568-4578. [CrossRef]

102. Shin, D.Y.; Kim, A.; Kang, H.J.; Park, S.; Kim, D.W.; Lee, S.S. Histone deacetylase inhibitor romidepsin induces efficient tumor cell lysis via selective down-regulation of LMP1 and c-MYC expression in EBV-positive diffuse large B-cell lymphoma. Cancer Lett. 2015, 364, 89-97. [CrossRef]

103. Vrzalikova, K.; Vockerodt, M.; Leonard, S.; Bell, A.; Wei, W.; Schrader, A.; Wright, K.L.; Kube, D.; Rowe, M.; Woodman, C.B.; et al. Down-regulation of BLIMP1 $\alpha$ by the EBV oncogene, LMP-1, disrupts the plasma cell differentiation program and prevents viral replication in B cells: Implications for the pathogenesis of EBV-associated B-cell lymphomas. Blood 2011, 117, 5907-5917. [CrossRef] [PubMed]

104. Fish, K.; Sora, R.P.; Schaller, S.J.; Longnecker, R.; Ikeda, M. EBV latent membrane protein 2A orchestrates p27kip1 degradation via Cks1 to accelerate MYC-driven lymphoma in mice. Blood 2017, 130, 2516-2526. [CrossRef] [PubMed]

105. Moody, C.A.; Scott, R.S.; Amirghahari, N.; Nathan, C.-A.; Young, L.S.; Dawson, C.W.; Sixbey, J.W. Modulation of the Cell Growth Regulator mTOR by Epstein-Barr Virus-Encoded LMP2A. J. Virol. 2005, 79, 5499-5506. [CrossRef] [PubMed]

106. Fitzsimmons, L.; Cartlidge, R.; Chang, C.; Sejic, N.; Galbraith, L.C.A.; Suraweera, C.D.; Grant, D.C.; Tierney, R.J.; Bell, A.I.; Herold, C.S.M.J.; et al. EBV BCL-2 homologue BHRF1 drives chemoresistance and lymphomagenesis by inhibiting multiple cellular pro-apoptotic proteins. Cell Death Differ. 2020, 1554-1568. [CrossRef]

107. Guo, R.; Jiang, C.; Zhang, Y.; Govande, A.; Trudeau, S.J.; Chen, F.; Fry, C.J.; Puri, R.; Wolinsky, E.; Schineller, M.; et al. MYC Controls the Epstein-Barr Virus Lytic Switch. Mol. Cell 2020, 78, 653-669.e8. [CrossRef]

108. Ishii, H.; Gobé, G.; Kawakubo, Y.; Sato, Y.; Ebihara, Y. Interrelationship between Epstein-Barr virus infection in gastric carcinomas and the expression of apoptosis-associated proteins. Histopathology 2001, 38, 111-119. [CrossRef]

109. Lima, V.P.; de Lima, M.A.P.; André, A.R.; Ferreira, M.V.P.; Barros, M.A.P.; Rabenhorst, S.H.B. H pylori (CagA) and Epstein-Barr virus infection in gastric carcinomas: Correlation With p53 mutation and c-MYC, Bcl-2 and Bax expression. World J. Gastroenterol. 2008, 14, 884-891. [CrossRef]

110. Lima, M.A.P.; Ferreira, M.V.P.; Barros, M.A.P.; Pardini, M.I.M.C.; Ferrasi, A.C.; Mota, R.M.S.; Rabenhorst, S.H.B. Relationship Between EBV Infection and Expression of Cellular Proteins c-MYC, Bcl-2, and Bax in Gastric Carcinomas. Diagnostic Mol. Pathol. 2008, 17, 82-89. [CrossRef]

111. Zhu, S.; Sun, P.; Zhang, Y.; Yan, L.; Luo, B. Expression of c-MYC and PCNA in Epstein-Barr virus-associated gastric carcinoma. Exp. Ther. Med. 2013, 5, 1030-1034. [CrossRef] [PubMed]

112. Luo, B.; Wang, Y.; Wang, X.F.; Gao, Y.; Huang, B.H.; Zhao, P. Correlation of Epstein-Barr virus and its encoded proteins with Helicobacter pylori and expression of c-met and c-MYC in gastric carcinoma. World J. Gastroenterol. 2006, 12, 1842-1848. [CrossRef] [PubMed]

113. Purdy, J.G.; Luftig, M.A. Reprogramming of cellular metabolic pathways by human oncogenic viruses. Curr. Opin. Virol. 2019, 39, 60-69. [CrossRef] [PubMed]

114. Ueda, K. KSHV genome replication and maintenance in latency. In Human Herpesviruses; Kawaguchi, Y., Mori, Y., Kimura, H., Eds.; Springer Singapore Pte. Limited: Singapore, 2018; pp. 299-320, ISBN 9789811072307.

115. Lo, A.K.-F.; Dawson, C.W.; Young, L.S.; Lo, K.-W. The role of metabolic reprogramming in $\gamma$-herpesvirus-associated oncogenesis. Int. J. Cancer 2017, 141, 1512-1521. [CrossRef] 
116. Liu, J.; Martin, H.J.; Liao, G.; Hayward, S.D. The Kaposi's Sarcoma-Associated Herpesvirus LANA Protein Stabilizes and Activates c-MYC. J. Virol. 2007, 81, 10451-10459. [CrossRef]

117. Fujimuro, M.; Wu, F.Y.; Aprhys, C.; Kajumbula, H.; Young, D.B.; Hayward, G.S.; Hayward, S.D. A novel viral mechanism for dysregulation of $\beta$-catenin in Kaposi's sarcoma-associated herpesvirus latency. Nat. Med. 2003, 9, 300-306. [CrossRef]

118. Stamos, J.L.; Weis, W.I. The $\beta$-catenin destruction complex. Cold Spring Harb. Perspect. Biol. 2013, 5, a007898. [CrossRef]

119. Bubman, D.; Guasparri, I.; Cesarman, E. Deregulation of c-MYC in primary effusion lymphoma by Kaposi's sarcoma herpesvirus latency-associated nuclear antigen. Oncogene 2007, 26, 4979-4986. [CrossRef]

120. Chang, H.C.; Hsieh, T.H.; Lee, Y.W.; Tsai, C.F.; Tsai, Y.N.; Cheng, C.C.; Wang, H.W. c-MYC and viral cofactor Kaposin B co-operate to elicit angiogenesis through modulating miRNome traits of endothelial cells. BMC Syst. Biol. 2016, 10, 1-16. [CrossRef]

121. Muralimanoharan, S.; Maloyan, A.; Mele, J.; Guo, C.; Myatt, L.G.; Myatt, L. MIR-210 modulates mitochondrial respiration in placenta with preeclampsia. Placenta 2012, 33, 816-823. [CrossRef]

122. Ma, M.; Ma, C.; Li, P.; Ma, C.; Ping, F.; Li, W.; Xu, L.; Zhang, H.; Sun, Q.; Li, Y. Low glucose enhanced metformin's inhibitory effect on pancreatic cancer cells by suppressing glycolysis and inducing energy stress via up-regulation of miR-210-5p. Cell Cycle 2020, 19, 2168-2181. [CrossRef] [PubMed]

123. Pranzini, E.; Leo, A.; Rapizzi, E.; Ramazzotti, M.; Magherini, F.; Giovannelli, L.; Caselli, A.; Cirri, P.; Taddei, M.L.; Paoli, P. miR-210-3p mediates metabolic adaptation and sustains DNA damage repair of resistant colon cancer cells to treatment with 5-fluorouracil. Mol. Carcinog. 2019, 58, 2181-2192. [CrossRef]

124. Du, Y.; Wei, N.; Ma, R.; Jiang, S.; Song, D. A miR-210-3p regulon that controls the Warburg effect by modulating HIF-1 $\alpha$ and p53 activity in triple-negative breast cancer. Cell Death Dis. 2020, 11, 1-12. [CrossRef]

125. Qiao, X.R.; Wang, L.; Liu, M.; Tian, Y.; Chen, T. MiR-210-3p attenuates lipid accumulation and inflammation in atherosclerosis by repressing IGF2. Biosci. Biotechnol. Biochem. 2020, 84, 321-329. [CrossRef] [PubMed]

126. Zhao, M.; Luo, R.; Liu, Y.; Gao, L.; Fu, Z.; Fu, Q.; Luo, X.; Chen, Y.; Deng, X.; Liang, Z.; et al. miR-3188 regulates nasopharyngeal carcinoma proliferation and chemosensitivity through a FOXO1-modulated positive feedback loop with mTOR-p-PI3K/AKT-cJUN. Nat. Commun. 2016, 7, 11309. [CrossRef] [PubMed]

127. Pepe, F.; Pagotto, S.; Soliman, S.; Rossi, C.; Lanuti, P.; Braconi, C.; Mariani-Costantini, R.; Visone, R.; Veronese, A. Regulation of miR-483-3p by the O-linked N-acetylglucosamine transferase links chemosensitivity to glucose metabolism in liver cancer cells. Oncogenesis 2017, 6, 1-8. [CrossRef]

128. Ji, H.; Yi, Q.; Chen, L.; Wong, L.; Liu, Y.; Xu, G.; Zhao, J.; Huang, T.; Li, B.; Yang, Y.; et al. Circulating miR-3197 and miR-2116-5p as novel biomarkers for diabetic retinopathy. Clin. Chim. Acta 2020, 501, 147-153. [CrossRef]

129. Yang, W.; Wang, J.; Chen, Z.; Chen, J.; Meng, Y.; Chen, L.; Chang, Y.; Geng, B.; Sun, L.; Dou, L.; et al. NFE2 induces miR-423-5p to promote gluconeogenesis and hyperglycemia by repressing the hepatic FAM3A-ATP-Akt pathway. Diabetes 2017, 66, 1819-1832. [CrossRef]

130. Wang, Y.; Chen, X.; Zhang, Y.; Song, J. Potential proteins targeted by let-7f-5p in HeLa cells. Biosci. Trends 2017, 11, 363-365. [CrossRef] [PubMed]

131. Fan, G.; Zhang, C.; Wei, X.; Wei, R.; Qi, Z.; Chen, K.; Cai, X.; Xu, L.; Tang, L.; Zhou, J.; et al. NEAT1/hsa-miR-372-3p axis participates in rapaMYCin-induced lipid metabolic disorder. Free Radic. Biol. Med. 2021, 167, 1-11. [CrossRef]

132. Fierro-Fernández, M.; Miguel, V.; Márquez-Expósito, L.; Nuevo-Tapioles, C.; Herrero, J.I.; Blanco-Ruiz, E.; Tituaña, J.; Castillo, C.; Cannata, P.; Monsalve, M.; et al. MiR-9-5p protects from kidney fibrosis by metabolic reprogramming. FASEB J. 2020, 34, 410-431. [CrossRef]

133. Wang, J.; Wang, B.; Ren, H.Q.; Chen, W. miR-9-5p inhibits pancreatic cancer cell proliferation, invasion and glutamine metabolism by targeting GOT1. Biochem. Biophys. Res. Commun. 2019, 509, 241-248. [CrossRef] [PubMed]

134. Yang, X.; Zhu, X.; Yan, Z.; Li, C.; Zhao, H.; Ma, L.; Zhang, D.; Liu, J.; Liu, Z.; Du, N.; et al. miR-489-3p/SIX1 Axis Regulates Melanoma Proliferation and Glycolytic Potential. Mol. Ther. Oncolytics 2020, 16, 30-40. [CrossRef]

135. Liu, N.; Feng, S.; Li, H.; Chen, X.; Bai, S.; Liu, Y. Long non-coding RNA MALAT1 facilitates the tumorigenesis, invasion and glycolysis of multiple myeloma via miR-1271-5p/SOX13 axis. J. Cancer Res. Clin. Oncol. 2020, 146, 367-379. [CrossRef]

136. Woo, S.Y.; Lee, S.Y.; Yu, S.L.; Park, S.J.; Kang, D.; Kim, J.S.; Jeong, I.B.; Kwon, S.J.; Hwang, W.J.; Park, C.R.; et al. MicroRNA-7-5p's role in the O-GlcNAcylation and cancer metabolism. Non-coding RNA Res. 2020, 5, 201-207. [CrossRef]

137. Wang, F.; Fan, M.; Zhou, X.; Yu, Y.; Cai, Y.; Wu, H.; Zhang, Y.; Liu, J.; Huang, S.; He, N.; et al. A positive feedback loop between TAZ and miR-942-3p modulates proliferation, angiogenesis, epithelial-mesenchymal transition process, glycometabolism and ROS homeostasis in human bladder cancer. J. Exp. Clin. Cancer Res. 2021, 40, 1-19. [CrossRef]

138. Deng, X.; Guo, B.; Fan, Y. Mir-153-3p suppresses cell proliferation, invasion and glycolysis of thyroid cancer through inhibiting e3f3 expression. OncoTargets Ther. 2021, 14, 519-529. [CrossRef]

139. Wang, T.; Zhai, M.; Xu, S.; Ponnusamy, M.; Huang, Y.; Liu, C.Y.; Wang, M.; Shan, C.; Shan, P.P.; Gao, X.Q.; et al. NFATc3-dependent expression of miR-153-3p promotes mitochondrial fragmentation in cardiac hypertrophy by impairing mitofusin-1 expression. Theranostics 2020, 10, 553-566. [CrossRef] [PubMed]

140. Baresova, P.; Pitha, P.M.; Lubyova, B. Kaposi sarcoma-associated herpesvirus vIRF-3 protein binds to F-box of Skp2 protein and acts as a regulator of c-MYC protein function and stability. J. Biol. Chem. 2012, 287, 16199-16208. [CrossRef] [PubMed]

141. Lubyova, B.; Kellum, M.J.; Frisancho, J.A.; Pitha, P.M. Stimulation of c-MYC transcriptional activity by vIRF-3 of Kaposi sarcoma-associated herpesvirus. J. Biol. Chem. 2007, 282, 31944-31953. [CrossRef] [PubMed] 
142. Lee, H.-R.; Doganay, S.; Chung, B.; Toth, Z.; Brulois, K.; Lee, S.; Kanketayeva, Z.; Feng, P.; Ha, T.; Jung, J.U. Kaposi's SarcomaAssociated Herpesvirus Viral Interferon Regulatory Factor 4 (vIRF4) Targets Expression of Cellular IRF4 and the MYC Gene To Facilitate Lytic Replication. J. Virol. 2014, 88, 2183-2194. [CrossRef]

143. Li, X.; Chen, S.; Feng, J.; Deng, H.; Sun, R. MYC Is Required for the Maintenance of Kaposi's Sarcoma-Associated Herpesvirus Latency. J. Virol. 2010, 84, 8945-8948. [CrossRef]

144. Park, A.; Oh, S.; Jung, K.L.; Choi, U.Y.; Lee, H.R.; Rosenfeld, M.G.; Jung, J.U. Global epigenomic analysis of KSHV-infected primary effusion lymphoma identifies functional MYC superenhancers and enhancer RNAs. Proc. Natl. Acad. Sci. USA 2020, 117, 21618-21627. [CrossRef]

145. Rosean, T.R.; Holman, C.J.; Tompkins, V.S.; Jing, X.; Krasowski, M.D.; Rose-John, S.; Janz, S. KSHV-encoded vIL-6 collaborates with deregulated c-MYC to drive plasmablastic neoplasms in mice. Blood Cancer J. 2016, 6, e398. [CrossRef] [PubMed]

146. Ahmad, A.; Groshong, J.S.; Matta, H.; Schamus, S.; Punj, V.; Robinson, L.J.; Gill, P.S.; Chaudhary, P.M. Kaposi's sarcoma associated herpesvirus-encoded viral FLICE inhibitory protein (vFLIP) K13 cooperates with MYC to promote lymphoma in mice. Cancer Biol. Ther. 2010, 10, 1033-1040. [CrossRef] [PubMed]

147. Sanchez, E.L.; Carroll, P.A.; Thalhofer, A.B.; Lagunoff, M. Latent KSHV Infected Endothelial Cells Are Glutamine Addicted and Require Glutaminolysis for Survival. PLoS Pathog. 2015, 11, 1-18. [CrossRef] [PubMed]

148. Sarnow, P.; Ho, Y.S.; Williams, J.; Levine, A.J. Adenovirus E1b-58kd tumor antigen and SV40 large tumor antigen are physically associated with the same $54 \mathrm{kd}$ cellular protein in transformed cells. Cell 1982, 28, 387-394. [CrossRef]

149. Yew, P.R.; Berk, A.J. Inhibition of p53 transactivation required for transformation by adenovirus early 1B protein. Nature 1992, 357, 82-85. [CrossRef] [PubMed]

150. Martin, M.E.D.; Berk, A.J. Adenovirus E1B 55K Represses p53 Activation In Vitro. J. Virol. 1998, 72, 3146-3154. [CrossRef]

151. Querido, E.; Morrison, M.R.; Chu-Pham-Dang, H.; Thirlwell, S.W.-L.; Boivin, D.; Branton, P.E. Identification of Three Functions of the Adenovirus E4orf6 Protein That Mediate p53 Degradation by the E4orf6-E1B55K Complex. J. Virol. 2001, 75, 2508. [CrossRef]

152. Cathomen, T.; Weitzman, M.D. A Functional Complex of Adenovirus Proteins E1B-55kDa and E4orf6 Is Necessary To Modulate the Expression Level of p53 but Not Its Transcriptional Activity. J. Virol. 2000, 74, 11407-11412. [CrossRef] [PubMed]

153. Cardoso, F.M.; Kato, S.E.M.; Huang, W.; Flint, S.J.; Gonzalez, R.A. An early function of the adenoviral E1B 55 kDa protein is required for the nuclear relocalization of the cellular p53 protein in adenovirus-infected normal human cells. Virology 2008, 378, 339-346. [CrossRef] [PubMed]

154. Zhao, L.Y.; Liao, D. Sequestration of p53 in the Cytoplasm by AdenovirusType 12 E1B 55-Kilodalton Oncoprotein Is Required for Inhibition ofp53-MediatedApoptosis. J. Virol. 2003, 77, 13171-13181. [CrossRef] [PubMed]

155. Muller, S.; Dobner, T. The adenovirus E1B-55K oncoprotein induces SUMO modification of p53. Cell Cycle 2008, 7, 754-758. [CrossRef] [PubMed]

156. Pennella, M.A.; Liu, Y.; Woo, J.L.; Kim, C.A.; Berk, A.J. Adenovirus E1B 55-Kilodalton Protein Is a p53-SUMO1 E3 Ligase That Represses p53 and Stimulates Its Nuclear Export through Interactions with Promyelocytic Leukemia Nuclear Bodies. J. Virol. 2010, 84, 12210-12225. [CrossRef]

157. Lomonosova, E.; Subramanian, T.; Chinnadurai, G. Mitochondrial localization of p53 during adenovirus infection and regulation of its activity by E1B-19K. Oncogene 2005, 24, 6796-6808. [CrossRef]

158. Teodoro, J.G.; Shore, G.C.; Branton, P.E. Adenovirus E1A proteins induce apoptosis by both p53-dependent and p53-independent mechanisms. Oncogene 1995, 11, 467-474.

159. Lowe, S.W.; Earl Ruley, H. Stabilization of the p53 tumor suppressor is induced by adenovirus 5 E1A and accompanies apoptosis. Genes Dev. 1993, 7, 535-545. [CrossRef]

160. Querido, E.; Teodoro, J.G.; Branton, P.E. Accumulation of p53 induced by the adenovirus E1A protein requires regions involved in the stimulation of DNA synthesis. J. Virol. 1997, 71, 3526-3533. [CrossRef]

161. Royds, J.A.; Hibma, M.; Dix, B.R.; Hananeia, L.; Russell, I.A.; Wiles, A.; Wynford-Thomas, D.; Braithwaite, A.W. P53 Promotes Adenoviral Replication and Increases Late Viral Gene Expression. Oncogene 2006, 25, 1509-1520. [CrossRef]

162. Wright, J.; Leppard, K.N. The Human Adenovirus 5 L4 Promoter Is Activated by Cellular Stress Response Protein p53. J. Virol. 2013, 87, 11617-11625. [CrossRef]

163. Chahal, J.S.; Flint, S.J. The p53 Protein Does Not Facilitate Adenovirus Type 5 Replication in Normal Human Cells. J. Virol. 2013, 87, 6044-6046. [CrossRef]

164. Steegenga, W.T.; van Laar, T.; Riteco, N.; Mandarino, A.; Shvarts, A.; van der Eb, A.J.; Jochemsen, A.G. Adenovirus E1A proteins inhibit activation of transcription by p53. Mol. Cell. Biol. 1996, 16, 2101-2109. [CrossRef] [PubMed]

165. Steegenga, W.T.; Shvarts, A.; Riteco, N.; Bos, J.L.; Jochemsen, A.G. Distinct Regulation of p53 and p73 Activity by Adenovirus E1A, E1B, and E4orf6 Proteins. Mol. Cell. Biol. 1999, 19, 3885-3894. [CrossRef] [PubMed]

166. Frost, J.R.; Mendez, M.; Soriano, A.M.; Crisostomo, L.; Olanubi, O.; Radko, S.; Pelka, P. Adenovirus 5 E1A-Mediated Suppression of p53 via FUBP1. J. Virol. 2018, 92, e00439-18. [CrossRef] [PubMed]

167. Horikoshi, N.; Usheva, A.; Chen, J.; Levine, A.J.; Weinmann, R.; Shenk, T. Two domains of p53 interact with the TATA-binding protein, and the adenovirus 13S E1A protein disrupts the association, relieving p53-mediated transcriptional repression. Mol. Cell. Biol. 1995, 15, 227-234. [CrossRef]

168. Lowe, S.W.; Jacks, T.; Housman, D.E.; Ruley, H.E. Abrogation of oncogene-associated apoptosis allows transformation of p53deficient cells. Proc. Natl. Acad. Sci. USA 1994, 91, 2026-2030. [CrossRef] [PubMed] 
169. Nevels, M.; Spruss, T.; Wolf, H.; Dobner, T. The adenovirus E4orf6 protein contributes to malignant transformation by antagonizing E1A-induced accumulation of the tumor suppressor protein p53. Oncogene 1999, 18, 9-17. [CrossRef]

170. Luo, K.; Ehrlich, E.; Xiao, Z.; Zhang, W.; Ketner, G.; Yu, X. Adenovirus E4orf6 assembles with Cullin5-ElonginB-ElonginC E3 ubiquitin ligase through an HIV/SIV Vif-like BC-box to regulate p53. FASEB J. 2007, 21, 1742-1750. [CrossRef] [PubMed]

171. Guo, H.; Shen, S.; Li, Y.; Bi, R.; Zhang, N.; Zheng, W.; Deng, Y.; Yang, Y.; Yu, X.F.; Wang, C.; et al. Adenovirus oncoprotein E4orf6 triggers Cullin5 neddylation to activate the CLR5 E3 ligase for p53 degradation. Biochem. Biophys. Res. Commun. 2019, 516, 1242-1247.

172. Zhou, L.; Jiang, Y.; Luo, Q.; Li, L.; Jia, L. Neddylation: A novel modulator of the tumor microenvironment. Mol. Cancer 2019, 18, 1-11. [CrossRef]

173. Blanchette, P.; Cheng, C.Y.; Yan, Q.; Ketner, G.; Ornelles, D.A.; Dobner, T.; Conaway, R.C.; Conaway, J.W.; Branton, P.E. Both BC-Box Motifs of Adenovirus Protein E4orf6 Are Required To Efficiently Assemble an E3 Ligase Complex That Degrades p53. Mol. Cell. Biol. 2004, 24, 9619-9629. [CrossRef] [PubMed]

174. Soria, C.; Estermann, F.E.; Espantman, K.C.; Oshea, C.C. Heterochromatin silencing of p53 target genes by a small viral protein. Nature 2010, 466, 1076-1081. [CrossRef]

175. Labuschagne, C.F.; Zani, F.; Vousden, K.H. Control of metabolism by p53 - Cancer and beyond. Biochim. Biophys. Acta Rev. Cancer 2018, 1870, 32-42. [CrossRef] [PubMed]

176. Lechner, M.S.; Mack, D.H.; Finicle, A.B.; Crook, T.; Vousden, K.H.; Laimins, L.A. Human papillomavirus E6 proteins bind p53 in vivo and abrogate p53-mediated repression of transcription. EMBO J. 1992, 11, 3045-3052. [CrossRef]

177. Scheffner, M.; Werness, B.A.; Huibregtse, J.M.; Levine, A.J.; Howley, P.M. The E6 oncoprotein encoded by human papillomavirus types 16 and 18 promotes the degradation of p53. Cell 1990, 63, 1129-1136. [CrossRef]

178. Werness, B.A.; Levine, A.J.; Howley, P.M. Association of human papillomavirus types 16 and 18 E6 proteins with p53. Science 1990, 248, 76-79. [CrossRef]

179. Li, S.; Hong, X.; Wei, Z.; Xie, M.; Li, W.; Liu, G.; Guo, H.; Yang, J.; Wei, W.; Zhang, S. Ubiquitination of the HPV oncoprotein E6 is critical for E6/E6AP-mediated p53 degradation. Front. Microbiol. 2019, 10, 1-11. [CrossRef]

180. Conrady, M.C.; Suarez, I.; Gogl, G.; Frecot, D.I.; Bonhoure, A.; Kostmann, C.; Cousido-Siah, A.; Mitschler, A.; Lim, J.; Masson, M.; et al. Structure of High-Risk Papillomavirus 31 E6 Oncogenic Protein and Characterization of E6/E6AP/p53 Complex Formation. J. Virol. 2020, 95, e00730-20. [CrossRef]

181. Yi, S.A.; Lee, D.H.; Kim, G.W.; Ryu, H.W.; Park, J.W.; Lee, J.; Han, J.; Park, J.H.; Oh, H.; Lee, J.; et al. HPV-mediated nuclear export of HP1 $\gamma$ drives cervical tumorigenesis by downregulation of p53. Cell Death Differ. 2020, 27, 2537-2551. [CrossRef] [PubMed]

182. Jones, D.L.; Thompson, D.A.; Münger, K. Destabilization of the RB tumor suppressor protein and stabilization of p53 contribute to HPV type 16 E7-induced apoptosis. Virology 1997, 239, 97-107.

183. Massimi, P.; Banks, L. Repression of p53 transcriptional activity by the HPV E7 proteins. Virology 1997, 227, 255-259. [CrossRef] [PubMed]

184. Fischer, M.; Uxa, S.; Stanko, C.; Magin, T.M.; Engeland, K. Human papilloma virus E7 oncoprotein abrogates the p53-p21-DREAM pathway. Sci. Rep. 2017, 7, 1-11. [CrossRef] [PubMed]

185. Prusinkiewicz, M.A.; Gameiro, S.F.; Ghasemi, F.; Dodge, M.J.; Zeng, P.Y.F.; Maekebay, H.; Barrett, J.W.; Nichols, A.C.; Mymryk, J.S. Survival-Associated Metabolic Genes in Human Papillomavirus-Positive Head and Neck Cancers. Cancers 2020, 12, 253. [CrossRef]

186. Yi, F.; Saha, A.; Murakami, M.; Kumar, P.; Knight, J.S.; Cai, Q.; Choudhuri, T.; Robertson, E.S. Epstein-Barr virus nuclear antigen 3C targets p53 and modulates its transcriptional and apoptotic activities. Virology 2009, 388, 236-247. [CrossRef] [PubMed]

187. Shukla, S.K.; Jha, H.C.; El-Naccache, D.W.; Robertson, E.S. An EBV recombinant deleted for residues 130-159 in EBNA3C can deregulate $\mathrm{p} 53 / \mathrm{Mdm} 2$ and Cyclin D1/CDK6 which results in apoptosis and reduced cell proliferation. Oncotarget 2016, 7, 18116-18134. [CrossRef] [PubMed]

188. Saha, A.; Bamidele, A.; Murakami, M.; Robertson, E.S. EBNA3C Attenuates the Function of p53 through Interaction with Inhibitor of Growth Family Proteins 4 and 5. J. Virol. 2011, 85, 2079-2088. [CrossRef]

189. Cai, Q.; Guo, Y.; Xiao, B.; Banerjee, S.; Saha, A.; Lu, J.; Glisovic, T.; Robertson, E.S. Epstein-barr virus nuclear antigen 3C stabilizes gemin3 to block p53-mediated apoptosis. PLoS Pathog. 2011, 7, 1-12. [CrossRef]

190. Shao, J.Y.; Ernberg, I.; Biberfeld, P.; Heiden, T.; Zeng, Y.X.; Hu, L.F. Epstein-Barr virus LMP1 status in relation to apoptosis, p53 expression and leucocyte infiltration in nasopharyngeal carcinoma. Anticancer Res. 2004, 24, 2309-2318.

191. Fries, K.L.; Miller, W.E.; Raab-Traub, N. Epstein-Barr virus latent membrane protein 1 blocks p53-mediated apoptosis through the induction of the A20 gene. J. Virol. 1996, 70, 8653-8659. [CrossRef]

192. Liu, M.T.; Chang, Y.T.; Chen, S.C.; Chuang, Y.C.; Chen, Y.R.; Lin, C.S.; Chen, J.Y. Epstein-Barr virus latent membrane protein 1 represses p53-mediated DNA repair and transcriptional activity. Oncogene 2005, 24, 2635-2646. [CrossRef] [PubMed]

193. Zeng, M.; Chen, Y.; Jia, X.; Liu, Y. The anti-apoptotic role of EBV-LMP1 in lymphoma cells. Cancer Manag. Res. 2020, 12, 8801-8811. [CrossRef] [PubMed]

194. Li, L.; Li, W.; Xiao, L.; Xu, J.; Chen, X.; Tang, M.; Dong, Z.; Tao, Q.; Cao, Y. Viral oncoprotein LMP1 disrupts p53-induced cell cycle arrest and apoptosis through modulating K63-linked ubiquitination of p53. Cell Cycle 2012, 11, 2327-2336. [CrossRef]

195. Wang, Q.; Lingel, A.; Geiser, V.; Kwapnoski, Z.; Zhang, L. Tumor Suppressor p53 Stimulates the Expression of Epstein-Barr Virus Latent Membrane Protein 1. J. Virol. 2017, 91, 1-14. [CrossRef] [PubMed] 
196. Zhang, Q.; Gutsch, D.; Kenney, S. Functional and physical interaction between p53 and BZLF1: Implications for Epstein-Barr virus latency. Mol. Cell. Biol. 1994, 14, 1929-1938. [CrossRef]

197. Sato, Y.; Shirata, N.; Kudoh, A.; Iwahori, S.; Nakayama, S.; Murata, T.; Isomura, H.; Nishiyama, Y.; Tsurumi, T. Expression of Epstein-Barr virus BZLF1 immediate-early protein induces p53 degradation independent of MDM2, leading to repression of p53-mediated transcription. Virology 2009, 388, 204-211. [CrossRef]

198. Sato, Y.; Kamura, T.; Shirata, N.; Murata, T.; Kudoh, A.; Iwahori, S.; Nakayama, S.; Isomura, H.; Nishiyama, Y.; Tsurumi, T. Degradation of phosphorylated p53 by viral protein-ECS E3 ligase complex. PLoS Pathog. 2009, 5, 1-9. [CrossRef] [PubMed]

199. Li, Z.; Chen, X.; Li, L.; Liu, S.; Yang, L.; Ma, X.; Tang, M.; Bode, A.M.; Dong, Z.; Sun, L.; et al. EBV encoded miR-BHRF1-1 potentiates viral lytic replication by downregulating host p53 in nasopharyngeal carcinoma. Int. J. Biochem. Cell Biol. 2012, 44, 275-279. [CrossRef]

200. Xu, D.M.; Kong, Y.L.; Wang, L.; Zhu, H.Y.; Wu, J.Z.; Xia, Y.; Li, Y.; Qin, S.C.; Fan, L.; Li, J.Y.; et al. EBV-mIR-BHRF1-1 targets p53 gene: Potential role in Epstein-Barr virus associated chronic lymphocytic leukemia. Cancer Res. Treat. 2020, 52, $492-504$. [CrossRef]

201. Zheng, X.; Wang, J.; Wei, L.; Peng, Q.; Gao, Y.; Fu, Y.; Lu, Y.; Qin, Z.; Zhang, X.; Lu, J.; et al. Epstein-Barr Virus MicroRNA miR-BART5-3p Inhibits p53 Expression. J. Virol. 2018, 92, e01022-18. [CrossRef]

202. Friborg, J.; Kong, W.P.; Hottlger, M.O.; Nabel, G.J. p53 Inhibition by the LANA protein of KSHV protects against cell death. Nature 1999, 402, 889-894. [CrossRef]

203. Cai, Q.L.; Knight, J.S.; Verma, S.C.; Zald, P.; Robertson, E.S. EC5S ubiquitin complex is recruited by KSHV latent antigen LANA for degradation of the VHL and p53 tumor suppressors. PLoS Pathog. 2006, 2, 1002-1012. [CrossRef]

204. Suzuki, T.; Isobe, T.; Kitagawa, M.; Ueda, K. Kaposi's sarcoma-associated herpesvirus-encoded LANA positively affects on ubiquitylation of p53. Biochem. Biophys. Res. Commun. 2010, 403, 194-197. [CrossRef] [PubMed]

205. Cai, Q.; Xiao, B.; Si, H.; Cervini, A.; Gao, J.; Lu, J.; Upadhyay, S.K.; Verma, S.C.; Robertson, E.S. Kaposi's sarcoma herpesvirus upregulates Aurora A expression to promote p53 phosphorylation and ubiquitylation. PLoS Pathog. 2012, 8, e1002566. [CrossRef]

206. Si, H.; Robertson, E.S. Kaposi's Sarcoma-Associated Herpesvirus-Encoded Latency-Associated Nuclear Antigen Induces Chromosomal Instability through Inhibition of p53 Function. J. Virol. 2006, 80, 697-709. [CrossRef]

207. Chen, W.; Hilton, I.B.; Staudt, M.R.; Burd, C.E.; Dittmer, D.P. Distinct p53, p53:LANA, and LANA Complexes in Kaposi's Sarcoma-Associated Herpesvirus Lymphomas. J. Virol. 2010, 84, 3898-3908. [CrossRef] [PubMed]

208. Ramalingam, D.; Kieffer-Kwon, P.; Ziegelbauer, J.M. Emerging themes from EBV and KSHV microRNA targets. Viruses 2012, 4, 1687-1710. [CrossRef] [PubMed]

209. Nakamura, H.; Li, M.; Zarycki, J.; Jung, J.U. Inhibition of p53 Tumor Suppressor by Viral Interferon Regulatory Factor. J. Virol. 2001, 75, 7572-7582. [CrossRef] [PubMed]

210. Seo, T.; Park, J.; Lee, D.; Hwang, S.G.; Choe, J. Viral Interferon Regulatory Factor 1 of Kaposi's Sarcoma-Associated Herpesvirus Binds to p53 and Represses p53-Dependent Transcription and Apoptosis. J. Virol. 2001, 75, 6193-6198. [CrossRef]

211. Rivas, C.; Thlick, A.-E.; Parravicini, C.; Moore, P.S.; Chang, Y. Kaposi's Sarcoma-Associated Herpesvirus LANA2 Is a B-CellSpecific Latent Viral Protein That Inhibits p53. J. Virol. 2001, 75, 429-438. [CrossRef]

212. Toledo, F.; Wahl, G.M. Regulating the p53 pathway: In vitro hypotheses, in vivo veritas. Nat. Rev. Cancer 2006, 6, 909-923. [CrossRef]

213. Baresova, P.; Musilova, J.; Pitha, P.M.; Lubyova, B. p53 Tumor Suppressor Protein Stability and Transcriptional Activity Are Targeted by Kaposi's Sarcoma-Associated Herpesvirus-Encoded Viral Interferon Regulatory Factor 3. Mol. Cell. Biol. 2014, 34, 386-399. [CrossRef]

214. Laura, M.V.; De La Cruz-Herrera, C.F.; Ferreirós, A.; Baz-Martínez, M.; Lang, V.; Vidal, A.; Muñoz-Fontela, C.; Rodríguez, M.S.; Collado, M.; Rivas, C. KSHV latent protein LANA2 inhibits sumo2 modification of p53. Cell Cycle 2015, 14, 277-282. [CrossRef] [PubMed]

215. Marcos-Villar, L.; Pérez-Girón, J.V.; Vilas, J.M.; Soto, A.; De La Cruz-Herrera, C.F.; Lang, V.; Collado, M.; Vidal, A.; Rodríguez, M.S.; Muñoz-Fontela, C.; et al. SUMOylation of p53 mediates interferon activities. Cell Cycle 2013, 12, 2809-2816. [CrossRef]

216. Müller, S.; Berger, M.; Lehembre, F.; Seeler, J.S.; Haupt, Y.; Dejean, A. c-Jun and p53 activity is modulated by SUMO-1 modification. J. Biol. Chem. 2000, 275, 13321-13329. [CrossRef] [PubMed]

217. Lee, H.-R.; Toth, Z.; Shin, Y.C.; Lee, J.-S.; Chang, H.; Gu, W.; Oh, T.-K.; Kim, M.H.; Jung, J.U. Kaposi's Sarcoma-Associated Herpesvirus Viral Interferon Regulatory Factor 4 Targets MDM2 To Deregulate the p53 Tumor Suppressor Pathway. J. Virol. 2009, 83, 6739-6747. [CrossRef] [PubMed]

218. West, J.T.; Wood, C. The role of Kaposi's sarcoma-associated herpesvirus/human herpesvirus-8 regulator of transcription activation (RTA) in control of gene expression. Oncogene 2003, 22, 5150-5163. [CrossRef]

219. Gwack, Y.; Hwang, S.; Byun, H.; Lim, C.; Kim, J.W.; Choi, E.-J.; Choe, J. Kaposi's Sarcoma-Associated Herpesvirus Open Reading Frame 50 Represses p53-Induced Transcriptional Activity and Apoptosis. J. Virol. 2001, 75, 6245-6248. [CrossRef] [PubMed]

220. Chudasama, P.; Konrad, A.; Jochmann, R.; Lausen, B.; Holz, P.; Naschberger, E.; Neipel, F.; Britzen-Laurent, N.; Stürzl, M. Structural proteins of Kaposi's sarcoma-associated herpesvirus antagonize p53-mediated apoptosis. Oncogene 2015, 34, 639-649. [CrossRef] 
221. Alzhanova, D.; Corcoran, K.; Bailey, A.G.; Long, K.; Taft-Benz, S.; Graham, R.L.; Broussard, G.S.; Heise, M.; Neumann, G.; Halfmann, P.; et al. Novel modulators of p53-signaling encoded by unknown genes of emerging viruses. PLoS Pathog. 2021, 17, 1-28. [CrossRef] [PubMed]

222. Chang, P.-C.; Li, M. Kaposi's Sarcoma-Associated Herpesvirus K-Cyclin Interacts with Cdk9 and Stimulates Cdk9-Mediated Phosphorylation of p53 Tumor Suppressor. J. Virol. 2008, 82, 278-290. [CrossRef]

223. Balistreri, G.; Viiliäinen, J.; Turunen, M.; Diaz, R.; Lyly, L.; Pekkonen, P.; Rantala, J.; Ojala, K.; Sarek, G.; Teesalu, M.; et al. Oncogenic Herpesvirus Utilizes Stress-Induced Cell Cycle Checkpoints for Efficient Lytic Replication. PLoS Pathog. 2016, 12, 1-26. [CrossRef] [PubMed]

224. Singh, R.K.; Lang, F.; Pei, Y.; Jha, H.C.; Robertson, E.S. Metabolic reprogramming of Kaposi's sarcoma associated herpes virus infected B-cells in hypoxia. PLoS Pathog. 2018, 14, 1-28. [CrossRef]

225. Choi, U.Y.; Lee, J.J.; Park, A.; Zhu, W.; Lee, H.R.; Choi, Y.J.; Yoo, J.S.; Yu, C.; Feng, P.; Gao, S.J.; et al. Oncogenic human herpesvirus hijacks proline metabolism for tumorigenesis. Proc. Natl. Acad. Sci. USA 2020, 117, 8083-8093. [CrossRef] [PubMed]

226. Moran, E. Interaction of adenoviral proteins with pRB and p53. FASEB J. 1993, 7, 880-885. [CrossRef] [PubMed]

227. Whyte, P.; Buchkovich, K.J.; Horowitz, J.M.; Friend, S.H.; Raybuck, M.; Weinberg, R.A.; Harlow, E. Association between an oncogene and an anti-oncogene: The adenovirus E1A proteins bind to the retinoblastoma gene product. Nature 1988, 334, 124 . [CrossRef]

228. King, C.R.; Zhang, A.; Tessier, T.M.; Gameiro, S.F.; Mymryk, J.S. Hacking the Cell: Network Intrusion and Exploitation by Adenovirus E1A. MBio 2018, 9, e00390-18. [CrossRef]

229. Ferrari, R.; Gou, D.; Jawdekar, G.; Johnson, S.A.; Nava, M.; Su, T.; Yousef, A.F.; Zemke, N.R.; Pellegrini, M.; Kurdistani, S.K.; et al. Adenovirus small E1A employs the lysine acetylases p300/CBP and tumor suppressor RB to repress select host genes and promote productive virus infection. Cell Host Microbe 2014, 16, 663-676. [CrossRef]

230. Ledl, A.; Schmidt, D.; Müller, S. Viral oncoproteins E1A and E7 and cellular LxCxE proteins repress SUMO modification of the retinoblastoma tumor suppressor. Oncogene 2005, 24, 3810-3818. [CrossRef] [PubMed]

231. Sohn, S.Y.; Hearing, P. Adenovirus early proteins and host sumoylation. MBio 2016, 7, 1-7. [CrossRef] [PubMed]

232. O'Connor, R.J.; Hearing, P. Mutually exclusive interaction of the adenovirus E4-6/7 protein and the retinoblastoma gene product with internal domains of E2F-1 and DP-1. J. Virol. 1994, 68, 6848-6862. [CrossRef]

233. Schaley, J.E.; Polonskaia, M.; Hearing, P. The Adenovirus E4-6/7 Protein Directs Nuclear Localization of E2F-4 via an ArginineRich Motif. J. Virol. 2005, 79, 2301-2308. [CrossRef]

234. Pelka, P.; Miller, M.S.; Cecchini, M.; Yousef, A.F.; Bowdish, D.M.; Dick, F.; Whyte, P.; Mymryk, J.S. Adenovirus E1A Directly Targets the E2F/DP-1 Complex. J. Virol. 2011, 85, 8841-8851. [CrossRef] [PubMed]

235. Dallaire, F.; Schreiner, S.; Blair, G.E.; Dobner, T.; Branton, P.E.; Blanchette, P. The Human Adenovirus Type 5 E4orf6/E1B55K E3 Ubiquitin Ligase Complex Can Mimic E1A Effects on E2F. mSphere 2016, 1. [CrossRef]

236. Dallaire, F.; Schreiner, S.; Blair, G.E.; Dobner, T.; Branton, P.E.; Blanchette, P. The Human Adenovirus Type 5 E4orf6/E1B55K E3 Ubiquitin Ligase Complex Enhances E1A Functional Activity. mSphere 2016, 1, 1-13. [CrossRef] [PubMed]

237. Balsitis, S.J.; Sage, J.; Duensing, S.; Münger, K.; Jacks, T.; Lambert, P.F. Recapitulation of the Effects of the Human Papillomavirus Type 16 E7 Oncogene on Mouse Epithelium by Somatic Rb Deletion and Detection of pRb-Independent Effects of E7 In Vivo. Mol. Cell. Biol. 2003, 23, 9094-9103. [CrossRef] [PubMed]

238. Balsitis, S.; Dick, F.; Lee, D.; Farrell, L.; Hyde, R.K.; Griep, A.E.; Dyson, N.; Lambert, P.F. Examination of the pRb-Dependent and pRb-Independent Functions of E7 In Vivo. J. Virol. 2005, 79, 11392-11402. [CrossRef]

239. Chellappan, S.; Kraus, V.B.; Kroger, B.; Munger, K.; Howley, P.M.; Phelps, W.C.; Nevins, J.R. Adeno virus E1A, simian virus 40 tumor antigen, and human papillomavirus E7 protein share the capacity to disrupt the interaction between transcription factor E2F and the retinoblastoma gene product. Proc. Natl. Acad. Sci. USA 1992, 89, 4549-4553. [CrossRef]

240. Gonzalez, S.L.; Stremlau, M.; He, X.; Basile, J.R.; Münger, K. Degradation of the Retinoblastoma Tumor Suppressor by the Human Papillomavirus Type 16 E7 Oncoprotein Is Important for Functional Inactivation and Is Separable from Proteasomal Degradation of E7. J. Virol. 2001, 75, 7583-7591. [CrossRef]

241. Collins, A.S.; Nakahara, T.; Do, A.; Lambert, P.F. Interactions with Pocket Proteins Contribute to the Role of Human Papillomavirus Type 16 E7 in the Papillomavirus Life Cycle. J. Virol. 2005, 79, 14769-14780. [CrossRef]

242. Zhang, B.; Chen, W.; Roman, A. The E7 proteins of low- and high-risk human papillomaviruses share the ability to target the pRB family member p130 for degradation. Proc. Natl. Acad. Sci. USA 2006, 103, 437-442. [CrossRef]

243. Swenson, J.J.; Mauser, A.E.; Kaufmann, W.K.; Kenney, S.C. The Epstein-Barr Virus Protein BRLF1 Activates S Phase Entry through E2F1 Induction. J. Virol. 1999, 73, 6540-6550. [CrossRef]

244. Zacny, V.L.; Wilson, J.; Pagano, J.S. The Epstein-Barr Virus Immediate-Early Gene Product, BRLF1, Interacts with the Retinoblastoma Protein during the Viral Lytic Cycle. J. Virol. 1998, 72, 8043-8051. [CrossRef] [PubMed]

245. Parker, G.A.; Touitou, R.; Allday, M.J. Epstein-Barr virus EBNA3C can disrupt multiple cell cycle checkpoints and induce nuclear division divorced from cytokinesis. Oncogene 2000, 19, 700-709. [CrossRef]

246. Szekely, L.; Selivanova, G.; Magnusson, K.P.; Klein, G.; Wiman, K.G. EBNA-5, an Epstein-Barr virus-encoded nuclear antigen, binds to the retinoblastoma and p53 proteins. Proc. Natl. Acad. Sci. USA 1993, 90, 5455-5459. [CrossRef] [PubMed]

247. Saha, A.; Lu, J.; Morizur, L.; Upadhyay, S.K.; AJ, M.P.; Robertson, E.S. E2F1 mediated apoptosis induced by the DNA damage response is blocked by EBV nuclear antigen 3C in lymphoblastoid cells. PLoS Pathog. 2012, 8, e1002573. [CrossRef] [PubMed] 
248. Pei, Y.; Banerjee, S.; Sun, Z.; Jha, H.C.; Saha, A.; Robertson, E.S. EBV Nuclear Antigen 3C Mediates Regulation of E2F6 to Inhibit E2F1 Transcription and Promote Cell Proliferation. PLoS Pathog. 2016, 12, 1-24. [CrossRef]

249. Pei, Y.; Wong, J.H.; Jha, H.C.; Tian, T.; Wei, Z.; Robertson, E.S. Epstein-Barr Virus Facilitates Expression of KLF14 by Regulating the Cooperative Binding of the E2F-Rb-HDAC Complex in Latent Infection. J. Virol. 2020, 94, 1-16. [CrossRef]

250. Lévy, P.; Bartosch, B. Metabolic reprogramming: A hallmark of viral oncogenesis. Oncogene 2016, 35, 4155-4164. [CrossRef] [PubMed]

251. Hume, A.J.; Kalejta, R.F. Regulation of the retinoblastoma proteins by the human herpesviruses. Cell Div. 2009, 4, 1-25. [CrossRef] [PubMed]

252. Radkov, S.A.; Kellam, P.; Boshoff, C. The latent nuclear antigen of Kaposi sarcoma-associated herpesvirus targets the retinoblastoma-E2F pathway and with the oncogene Hras transforms primary rat cells. Nat. Med. 2000, 6, 1121-1127. [CrossRef]

253. Godden-Kent, D.; Talbot, S.J.; Boshoff, C.; Chang, Y.; Moore, P.; Weiss, R.A.; Mittnacht, S. The cyclin encoded by Kaposi's sarcoma-associated herpesvirus stimulates cdk6 to phosphorylate the retinoblastoma protein and histone H1. J. Virol. 1997, 71, 4193-4198. [CrossRef] [PubMed]

254. Marcos-Villar, L.; Gallego, P.; Muñoz-Fontela, C.; De La Cruz-Herrera, C.F.; Campagna, M.; González, D.; Lopitz-Otsoa, F.; Rodríguez, M.S.; Rivas, C. Kaposi's sarcoma-associated herpesvirus lana2 protein interacts with the pocket proteins and inhibits their sumoylation. Oncogene 2014, 33, 495-503. [CrossRef] [PubMed]

255. He, M.; Cheng, F.; da Silva, S.R.; Tan, B.; Sorel, O.; Gruffaz, M.; Li, T.; Gao, S.-J. Molecular Biology of KSHV in Relation to HIV / AIDS-Associated Oncogenesis BT-HIV/AIDS-Associated Viral Oncogenesis. In HIV/AIDS-Associated Viral Oncogenesis; Meyers, C., Ed.; Springer International Publishing: Hershey, PA, USA, 2019; pp. 23-62, ISBN 978-3-030-03502-0.

256. Cermelli, S.; Jang, I.S.; Bernard, B.; Grandori, C. Synthetic lethal screens as a means to understand and treat MYC-driven cancers. Cold Spring Harb. Perspect. Med. 2014, 4, a014209. [CrossRef]

257. Toyoshima, M.; Howie, H.L.; Imakura, M.; Walsh, R.M.; Annis, J.E.; Chang, A.N.; Frazier, J.; Chau, B.N.; Loboda, A.; Linsley, P.S.; et al. Functional genomics identifies therapeutic targets for MYC-driven cancer. Proc. Natl. Acad. Sci. USA 2012, 109, 9545-9550. [CrossRef] [PubMed]

258. Mast, F.D.; Navare, A.T.; van der Sloot, A.M.; Coulombe-Huntington, J.; Rout, M.P.; Baliga, N.S.; Kaushansky, A.; Chait, B.T.; Aderem, A.; Rice, C.M.; et al. Crippling life support for SARS-CoV-2 and other viruses through synthetic lethality. J. Cell Biol. 2020, 219, 1-15. [CrossRef] [PubMed]

259. Dodge, M.J.; MacNeil, K.M.; Tessier, T.M.; Weinberg, J.B.; Mymryk, J.S. Emerging Antiviral Therapeutics for Human Adenovirus Infection: Recent Developments and Novel Strategies. Antiviral Res. 2021, 188, 105034. [CrossRef] 